\title{
Glucosylceramide synthase upregulates MDR1 expression in the regulation of cancer drug resistance through $c S r c$ and $\beta$-catenin signaling
}

\author{
Yong-Yu Liu¹, Vineet Gupta1, Gauri A Patwardhan1', Kaustubh Bhinge1, Yunfeng Zhao², Jianxiong Bao3, \\ Harihara Mehendale ${ }^{4}$, Myles C Cabot ${ }^{5}$, Yu-Teh Li and S Michal Jazwinski ${ }^{7}$
}

\begin{abstract}
Background: Drug resistance is the outcome of multiple-gene interactions in cancer cells under stress of anticancer agents. MDR1 overexpression is most commonly detected in drug-resistant cancers and accompanied with other gene alterations including enhanced glucosylceramide synthase (GCS). MDR1 encodes for P-glycoprotein that extrudes anticancer drugs. Polymorphisms of MDR1 disrupt the effects of P-glycoprotein antagonists and limit the success of drug resistance reversal in clinical trials. GCS converts ceramide to glucosylceramide, reducing the impact of ceramideinduced apoptosis and increasing glycosphingolipid (GSL) synthesis. Understanding the molecular mechanisms underlying MDR1 overexpression and how it interacts with GCS may find effective approaches to reverse drug resistance.

Results: MDR1 and GCS were coincidently overexpressed in drug-resistant breast, ovary, cervical and colon cancer cells; silencing GCS using a novel mixed-backbone oligonucleotide (MBO-asGCS) sensitized these four drug-resistant cell lines to doxorubicin. This sensitization was correlated with the decreased MDR1 expression and the increased doxorubicin accumulation. Doxorubicin treatment induced GCS and MDR1 expression in tumors, but MBO-asGCS treatment eliminated "in-vivo" growth of drug-resistant tumor (NCI/ADR-RES). MBO-asGCS suppressed the expression of MDR1 with GCS and sensitized NCI/ADR-RES tumor to doxorubicin. The expression of P-glycoprotein and the function of its drug efflux of tumors were decreased by 4 and 8 times after MBO-asGCS treatment, even though this treatment did not have a significant effect on P-glycoprotein in normal small intestine. GCS transient transfection induced MDR1 overexpression and increased P-glycoprotein efflux in dose-dependent fashion in OVCAR-8 cancer cells. GSL profiling, silencing of globotriaosylceramide synthase and assessment of signaling pathway indicated that GCS transfection significantly increased globo series GSLs (globotriaosylceramide Gb3, globotetraosylceramide Gb4) on GSL-enriched microdomain (GEM), activated cSrc kinase, decreased $\beta$-catenin phosphorylation, and increased nuclear $\beta$-catenin. These consequently increased MDR1 promoter activation and its expression. Conversely, MBO-asGCS treatments decreased globo series GSLs (Gb3, Gb4), cSrc kinase and nuclear $\beta$-catenin, and suppressed MDR-1 expression in dose-dependent pattern.
\end{abstract}

Conclusion: This study demonstrates, for the first time, that GCS upregulates MDR1 expression modulating drug resistance of cancer. GSLs, in particular globo series GSLs mediate gene expression of MDR1 through cSrc and $\beta$-catenin signaling pathway.

\section{Background}

Chemotherapy is the principal treatment option for patients with late stage cancers. Despite considerable advances in

* Correspondence: yliu@ulm.edu

1 Department of Basic Pharmaceutical Sciences, University of Louisiana at Monroe, Monroe, Louisiana 71209, USA

Full list of author information is available at the end of the article drug discovery, metastatic solid malignancies remain incurable, due to their poor response to most of the conventional antineoplastic agents. Acquired drug resistance of cancer cells severely limits the success of chemotherapy, particular in solid tumors $[1,2]$. The ABCB1 transporter, known as Pglycoprotein (P-gp) is encoded by human multidrug resis- 
tance 1 gene $(M D R 1)$ and is an important mediator of drug resistance $[2,3]$. Like other membrane transport proteins in $\mathrm{ABC}$ (ATP binding cassette) family, P-gp is found in various cellular membranes of organisms from bacteria to mammals. P-gp plays roles in the absorption, distribution, and excretion of pharmacological compounds in normal tissues [4,5]. However, overexpression of MDRI in tumors results in increase of P-gp and active effluxing of a variety of natural product anticancer agents from cells $[2,6]$. The polymorphism of $M D R 1$, particularly the 'silent' polymorphism, blocks the effects of currently available P-gp antagonists and thus limits the success of these agents in clinical trials [7-10].

Drug resistance is the outcome of multiple-gene interactions in cancer cells under the stress of antineoplastic agents. Several drug-resistant markers including Bcl-2, mutant p53, and glucosylceramide synthase (GCS) are overexpressed in drug-resistant cancers [5,11-13]. However, little is known about the molecular mechanism underlying $M D R 1$ overexpression and how it interacts with other genes to impart drug-resistance. Recently, an emerging body of evidence indicates a curious association of multidrug resistance with ceramide glycosylation [13-18]. GCS (UDP-glucose:ceramide glucosyltransferase, $U G C G$ ) transfers a glucose residue from UDP-glucose to ceramide and produces glucosylceramide $[19,20]$. This first step in glycosphingolipid (GSL) synthesis tightly regulates the production of all upstream GSLs [21]. Ceramide, a lipid second messenger, induces growth arrest or apoptosis in cancer cells; this induced-apoptosis is in part responsible for the therapeutic efficiency of antineoplastic regimens including anthracyclines, taxanes, and vinca alkaloids and radiation therapy [15,22-25]. Overexpression of GCS can result in drug resistance, as introduction of GCS confers cell resistance to doxorubicin, daunorubicin, and tumor necrosis factor- $\alpha[16,26,27]$. GCS is overexpressed in many MDR cancer cell lines [17,28], and in leukemia, breast cancer, and renal cell cancer [29-31]. Interestingly, GCS is coincidently overexpressed with MDRI in drug-resistant cells $[28,32]$ and in leukemia cells from patients who have poor-response to chemotherapy $[31,33]$. We have studied the effects of ceramide glycosylation on MDRI and found that GCS upregulates $M D R I$ expression through activation of $\mathrm{cSrc}$ and $\beta$-catenin signaling.

\section{Results}

Silencing GCS represses MDR 1 expression and sensitizes cancer cells to chemotherapeutic agents

We observed the role of GCS in the regulation of MDRI expression in NCI/ADR-RES and its GCS transfectants. GCS protein levels were increased in NCI/ADR-RES/GCS cells and significantly decreased in NCI/ADR-RES/asGCS cells (Figure 1A). Consistent with these, GCS enzyme activity was decreased to $52 \%(0.9$ vs. $1.7 \mathrm{GC} / \mathrm{Cer})$ in $\mathrm{NCI} /$
ADR-RES/asGCS cells, whereas the activity was increased to $110 \%$ (1.9 vs. $1.7 \mathrm{GC} / \mathrm{Cer})$ in NCI/ADR-RES/GCS, as compared with parental NCI/ADR-RES cells (Figure 1A,B). Coordinately, P-gp was significantly decreased to $40 \%$ in NCI/ADR-RES/asGCS cells, as detected by Western blotting and immunostaining (Figure 1A,C). HPLC assays indicated that cellular accumulation of doxorubicin was increased by 3 -fold in NCI/ADR-RES/asGCS cells $\left(2.54 \pm 0.15\right.$ vs. $0.80 \pm 0.51 \mathrm{ng} / 10^{5}$ cells $)$ as compared with NCI/ADR-RES cells (Figure 1D). Substantial intracellular accumulation of doxorubicin was also observed in NCI/ ADR-RES/asGCS cells under fluorescence microscopy (Figure 1D).

MDRI and GCS have been shown to be coincidently overexpressed in several drug-resistant cell lines [17,28]. To validate the association of $M D R 1$ expression with GCS, we assessed MDRI expression in four different types of cancer cells, in the absence and presence of GCS silencing with MBO-asGCS (a mixed-backbone oligonucleotide against human GCS) [34,35]. Results showed that GCS protein levels were decreased to $40 \%, 45 \%, 56 \%$ and $20 \%$ of control, respectively in drug-resistant human A2780-AD ovary cancer, KB-A1 cervical cancer, SW620/AD colon cancer, and murine EMT6/AR1 breast cancer cells treated with MBO-asGCS (50 nM, 7 days) (Figure 2A). Consistently, MBO-asGCS treatments decreased P-gp protein levels to $10 \%, 5 \%, 2 \%$ and $20 \%$ of control in these cell lines. Furthermore, MBO-asGCS substantially sensitized cells to doxorubicin; the $\mathrm{EC}_{50}$ values for doxorubicin were decreased by 4-fold in A-2780AD, 43-fold in KB-A1, 7fold in SW620/AD, and 6-fold in EMT6/AR1 cells, respectively (Figure 2B). These data indicate that suppressing GCS can repress MDR1 expression and reverse cellular resistance to anticancer agents.

\section{Silencing GCS represses MDR1 expression and restores tumor sensitivity to doxorubicin}

Inoculation of NCI/ADR-RES cells into athymic mice generated MDR tumor xenografts. Mice with MDR xenografts were treated with MBO-asGCS (1 mg/kg per 3 days) alone or combined with doxorubicin $(2 \mathrm{mg} / \mathrm{kg}$ per week). As shown in Figure 3A, MBO-asGCS treatment significantly decreased tumor growth and increased the sensitivity of these tumors to doxorubicin. The combination treatment (MBO-asGCS + Dox) decreased tumor volumes to $45 \%$ (187vs. $\left.411 \mathrm{~mm}^{3}, \mathrm{p}<0.01\right)$ and $20 \%\left(187 v s .913 \mathrm{~mm}^{3}, \mathrm{p}<\right.$ 0.001 ), respectively, as compared with doxorubicin or saline treatment. Western blot analysis revealed that GCS and P-gp protein levels were increased 2-fold and 4-fold in tumors treated with doxorubicin, as compared with saline (Figure 3B). However, MBO-asGCS decreased both GCS and $\mathrm{P}$-gp protein levels by approximately 4-fold in tumors treated with MBO-asGCS alone or MBO-asGCS combined with doxorubicin, as compared with saline and doxorubicin 
A

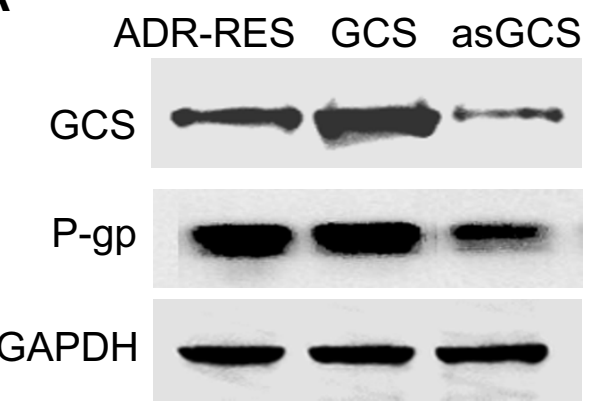

B

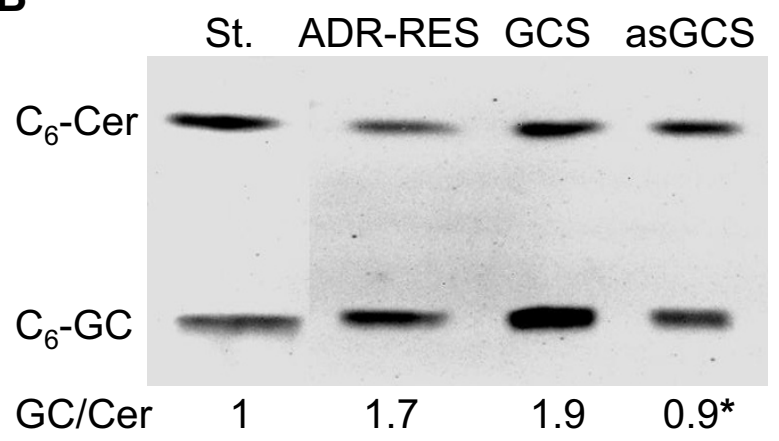

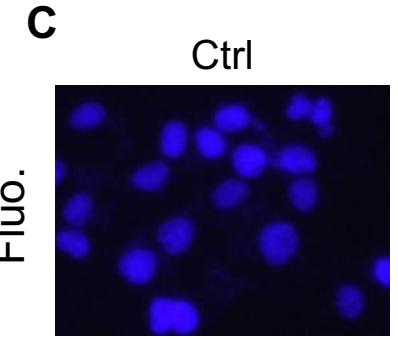
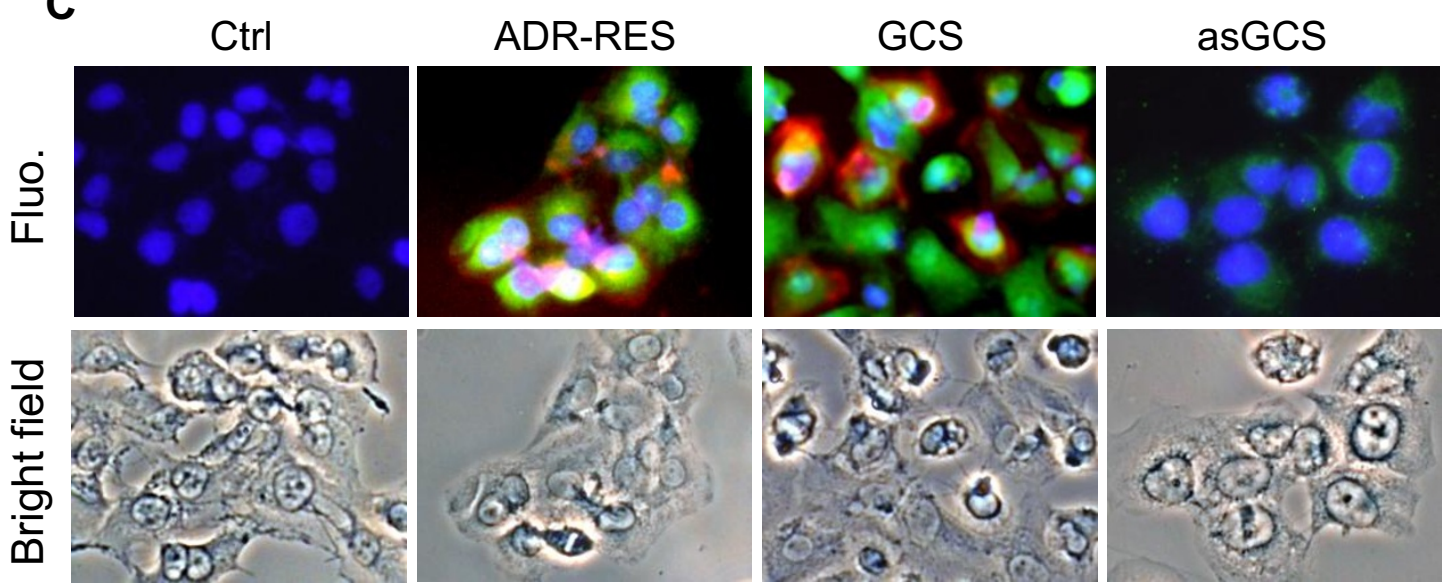

D

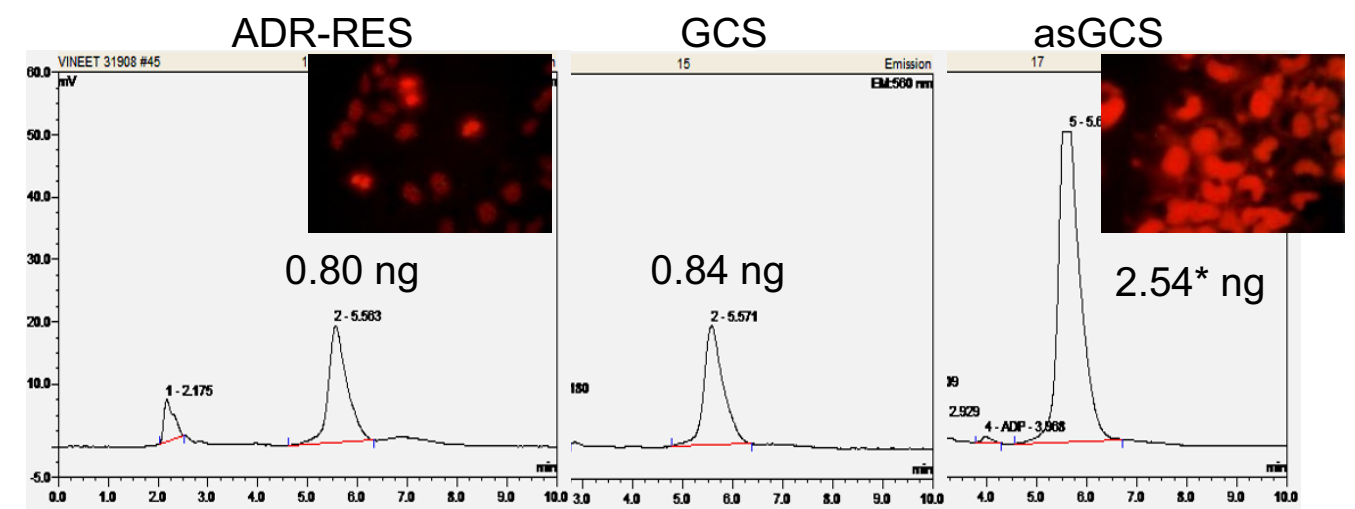

Figure 1 Effects of GCS on P-gp in NCI/ADR-RES Transfectants. (A) GCS and P-gp proteins detected by Western blot. Detergent-soluble protein (50 $\mathrm{\mu g}$ /lane) from NCI/ADR-RES (ADR-RES), NCI-ADR-RES/GCS (GCS) and NCI/ADR-RES/asGCS (asGCS) cells was immunoblotted with anti-GCS or antiP-gp antibody. GAPDH was used as loading control. (B) Ceramide glycosylation catalyzed by GCS. Cells were incubated with NBD C6-Cer (100 nM) in $1 \%$ BSA RPMI- 1640 medium, at $37^{\circ} \mathrm{C}$ for $2 \mathrm{hr}$. C6-Cer and C6-GlcCer were identified on chromatograms with commercial standard (St.) and measured using spectrophotometry. *, $p<0.001$ compared to ADR-RES cells. (C) Immunostaining of GCS and P-gp. Cells were incubated with anti-human GCS (green) and anti-P-gp (red) following addition of Alexa 488- and Alexa 667-conjugated secondary antibodies. DAPI in mounting solution was used for nucleus counterstaining (blue). Ctrl, NCI/ADR-RES cells were incubated with the secondary antibodies alone, as specificity control; Fluo, merged fluorescence microphotograph (× 200). (D) Doxorubicin accumulation. After $1 \mathrm{hr}$ incubation with doxorubicin $(0.1 \mathrm{mg} / \mathrm{ml})$, cellular doxorubicin was documented by fluorescence microscopy $(\times 200)$ and analyzed by HPLC, following methanol extraction. Doxorubicin amount was normalized to 100,000 cells. ${ }^{*}, \mathrm{p}<0.001$ 
groups (Figure 3B). These findings were confirmed in tumor tissues after immunostaining for GCS and P-gp (Figure $3 \mathrm{C})$.

In agreement with its repressive effect on P-gp protein, MBO-asGCS significantly increased doxorubicin accumulation in tumor tissues. As shown in Figure 4A, MBO-asSGCS treatment augmented tumor accumulation of doxorubicin by 8 -fold (78 pg/mg vs. $10 \mathrm{pg} / \mathrm{mg}$ ) and 2-fold (59 pg/mg vs. $28 \mathrm{pg} / \mathrm{mg}$ ) after 4 and $24 \mathrm{hrs}$ of doxorubicin administration, compared to the saline group, respectively. Meanwhile, serum levels of doxorubicin decreased in the MBO-asGCS group. Further assessment using Flutax-2 (Oregon green 488-paclitaxel, a substrate of the P-gp pump) revealed that paclitaxel accumulation was increased 4-fold (11.41\% vs. 3.32\% of total, $\mathrm{p}<0.001$, Figure 4B), since that paclitaxel efflux decreased by 8 -fold (1.66\% vs. $13.2 \%$ of accumulated, $\mathrm{p}<0.001$ ) in tumors treated with MBO-asGCS (Figure 4C). MBO-asGCS treatments did not have a significant effect on P-gp of normal small intestine. These results indicate that silencing GCS by MBO-asGCS efficiently represses $M D R 1$ expression and reverses in vivo drug resistance.

\section{GCS upregulates MDR1 expression through cSrc kinase and}

\section{$\beta$-catenin signaling}

We transiently transfected GCS in human OVCAR-8 ovarian carcinoma cells, which express low level of MDRl [36], in order to explore putative mechanisms underlying GCS upregulation of $M D R 1$. One week after the transfection, GCS protein levels were elevated by 10 -fold, 20 -fold and 25 -fold in cells transfected with increasing amounts of GCS plasmid DNA (2, 4, and $8 \mu \mathrm{g} / \mathrm{dish}$ ) (Figure 5A). Interestingly, the levels of phosphorylated cSrc and FAK proteins were enhanced corresponding to GCS levels, even though the total cSrc levels remained relatively unchanged. Nuclear $\beta$-catenin levels were elevated by 5 - to 10 -fold whereas phosphorylated $\beta$-catenin declined as GCS, p-cSrc, and p-FAK increased in these cells (at 4 , and $8 \mu \mathrm{g} / \mathrm{dish}$ ). Pgp protein levels were elevated by 2 to 3 -fold concomitant with $M D R 1$ promoter activities in these cells (4 and $8 \mu \mathrm{g}$ / dish) (Figure 5B). The pyrazolo pyrimidine (PP2), a Src kinase inhibitor [37,38] selectively decreased the levels of phosphorylated cSrc (not p-FAK) and increased phosphorylated $\beta$-catenin, but did not decrease Gb3 synthase of cells after GCS transfection ( $8 \mathrm{mg} /$ dish, Figure $5 \mathrm{~A})$. The PP2 treatments blocked the stimulation effect of GCS on nuclei $\beta$-catenin, further $M D R 1$ promoter activity and P-gp expression (Figure 5A,B). We also assessed the cellular accumulation and activity of P-gp using Flutax-2. As shown in Figure 5C, paclitaxel accumulation was decreased to $60 \%$ and $47 \%$ of control in cells transfected with increasing amounts of GCS plasmid (4, $8 \mu \mathrm{g}$ DNA/dish), respectively, as compared with mock transfection. Conversely, cell efflux of paclitaxel was elevated to $153 \%$ and $212 \%$ over control in these transfectants. Inhibition of cSrc kinase by PP2 treatment eliminated the effects of GCS transfection on P-gp activity in the accumulation and efflux of paclitaxel (Figure 5C).

\section{A}

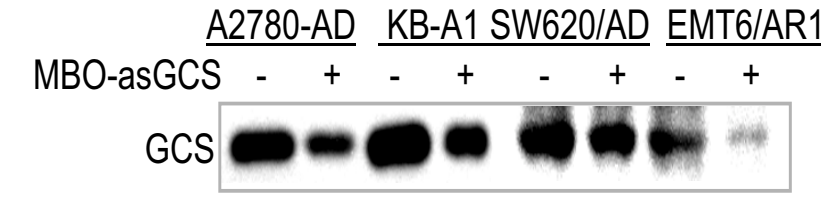

GCS/GAPDH $10040^{*} 10045^{*} 10056^{*} 10020^{*}$
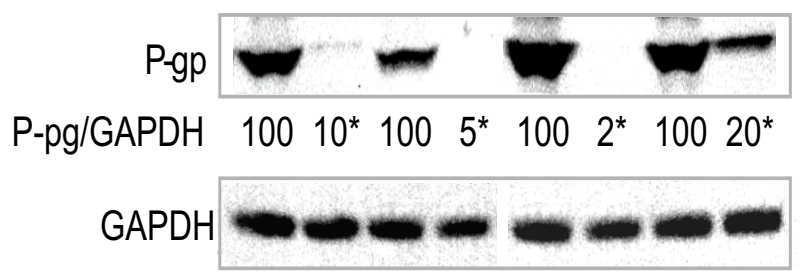

B

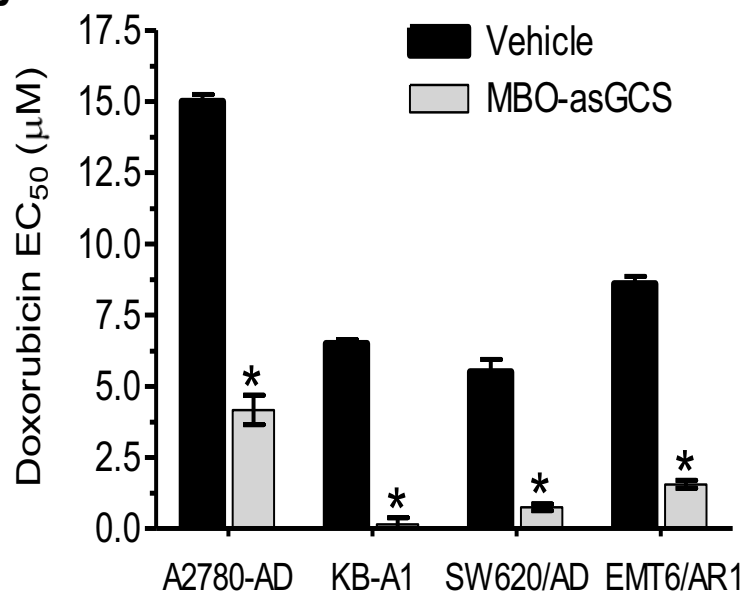

Figure 2 Silencing of GCS by MBO-asGCS Represses MDR1 Expression and Sensitizes Drug-Resistant Cancer Cells. (A) P-gp and GCS in drugresistant cancer cells. Cells were cultured in growth medium for $24 \mathrm{hr}$, and then treated with vehicle or MBO-asGCS (50 nM) for an additional $48 \mathrm{hr}$. Equal amounts of protein ( $50 \mathrm{\mu g} / \mathrm{lane}$ ) were resolved by 4-20\% gradient SDS-PAGE and immunoblotted with anti-GCS and anti-P-gp antibodies. GAPDH was used as end point control, and GCS/GAPDH or P-gp/GAPDH represents optical densities of the bands. - , vehicle (Lipofectamine 2000); +, MBOasGCS (50 nM). *, $p<0.001$ compared with vehicle treatment. (B) Cell response to doxorubicin. After pretreatment of MBO-asGCS (50 nM) or vehicle, cells were incubated with 5\% FBS medium at the presence of doxorubicin for an additional $72 \mathrm{hr} .{ }^{*}, \mathrm{p}<0.001$ compared with vehicle. 


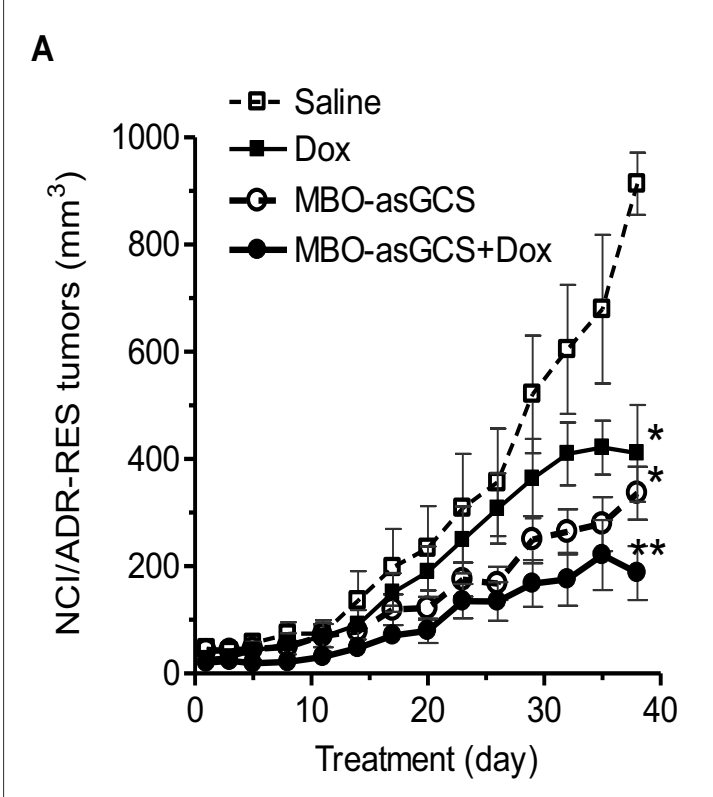

B
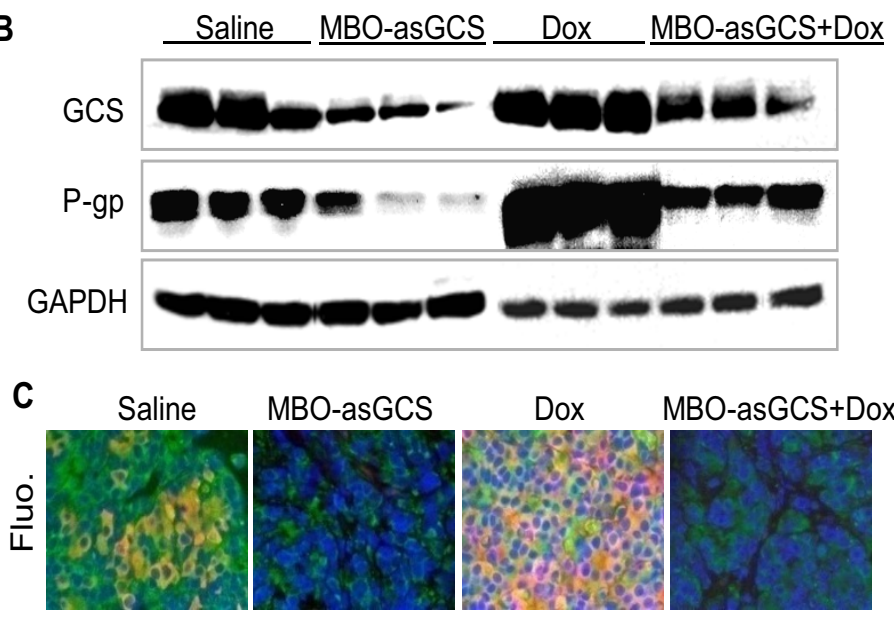

MBO-asGCS+Dox
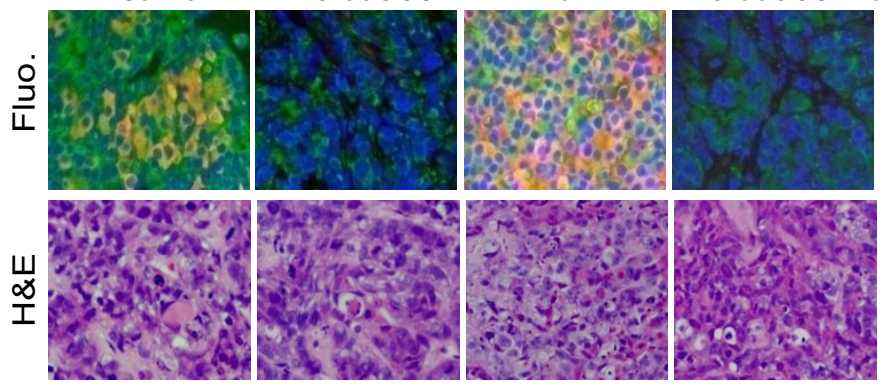

Figure 3 Silencing of GCS by MBO-asGCS Represses MDR1 Expression and Reverses Tumor Resistance to Doxorubicin in vivo. (A) Tumor growth. Tumors generated from NCI/ADR-RES cells ( $3 \mathrm{~mm}$ in diameter, 10 mice/group) were treated with MBO-asGCS (1 mg/kg every 3 days) or doxorubicin ( $2 \mathrm{mg} / \mathrm{kg} /$ week) and combination thereof. Data represent the mean $\pm \mathrm{SE} ;{ }^{*}, \mathrm{p}<0.001$ compared to saline group (open squares); ${ }^{*}, \mathrm{p}<0.001$ compared to doxorubicin treatment (solid squares). (B) Western blots of tumor tissues. After treatments, extracted tumor proteins $(100 \mu \mathrm{g} / \mu \mathrm{l}, \mathrm{hree}$ samples per group) were resolved by 4-20\% SDS-PAGE and immunoblotted with anti-GCS or anti-P-gp antibodies, respectively. (C) Immunostaining. After retrieval, antigens on tissue sections $(5 \mu \mathrm{m})$ were recognized by anti-GCS (green) and anti-P-gp (red) antibodies with fluorescence conjugated secondary antibodies. Microphotographs of merged fluorescence (Fluo.) with H\&E staining (H\&E) were originally magnified by 200.

\section{Silencing GCS represses MDR1 transactivation via inhibition of cSrc and $\beta$-catenin signaling}

We silenced GCS with MBO-asGCS in NCI/ADR-RES cells that overexpressed GCS and $M D R 1$, to verify the mechanism underlying GCS modulation of MDR1. After one week of MBO-asGCS treatments, GCS protein levels, but neither GD3 synthase nor Gb3 synthase, were decreased to $30 \%, 5 \%$ and $2 \%$ in cells treated with increasing concentrations of MBO-asGCS (50, 100, $200 \mathrm{nM})$, as compared with vehicle control, respectively (Figure 6A). The levels of the phosphorylated cSrc and FAK proteins, but not the total cSrc, were correspondingly decreased with GCS protein levels. Interestingly, nuclear $\beta$-catenin was decreased to approximately $10 \%$, whereas phosphorylated $\beta$-catenin was increased as the levels of GCS, p-cSrc, and pFAK were decreased in these cells after MBO-asGCS treatments. P-gp protein levels were decreased to $85 \%, 30 \%$ and $25 \%$ with decreases in MDRl promoter activity of cells treated with increasing concentrations of MBO-asGCS (50, $100,200 \mathrm{nM}$ ) (Figure 6B). Sequentially, we found that cellular accumulation of paclitaxel was elevated by 2.5 -fold, 11-fold and 22-fold in cells treated with MBO-asGCS, compared to vehicle control, respectively (Figure 6C). Conversely, cell efflux of paclitaxel was reduced to $89 \%, 48 \%$, and $31 \%$ in cell after these treatments. As anticipated, vera- pamil treatment $(10 \mu \mathrm{M})$ inhibited P-gp function, as effectively as MBO-asGCS (50 nM) in the cellular accumulation and efflux of paclitaxel in NCI/ADR-RES cells (Figure $6 \mathrm{C})$.

\section{Globo series GSLs modulate MDR 1 expression}

It has been reported that glycosphingolipids-enriched microdomains (GEMs) or rafts on cell membranes can mediate cSrc kinase activation [39-41]. To clarify which GSL has a major role in mediating $M D R 1$ expression, we analyzed GSL profiles of NCI/ADR-RES variants. It was found that the levels of globo series GSLs including globotriaosylceramide $(\mathrm{Gb} 3)$ and globotetraosylceramide $(\mathrm{Gb} 4)$ were significantly increased in NCI/ADR-RES/GCS cells and decreased in NCI/ADR-RES/asGCS cells (Figure 7A). On the other hand, $\mathrm{N}$-acetylneuraminyl- $\alpha 2,3$-galactosyl$\beta 1,4$-glucosyl ceramide (GM3) and $\mathrm{N}$-acetylgalactosaminyl- $\beta 1,4-(\alpha 2,3 \mathrm{~N}$-acetylneuraminyl) galactosyl- $\beta 1,4$-glucosyl ceramide (GM2) were increased in NCI/ADR-RES/ asGCS cells. As a receptor for verocytotoxin, the levels of $\mathrm{Gb3}$ on cells are associated with the cytotoxicity of verocytotoxin [42-44]. To assess the levels of Gb3 in NCI/ADRRES variants, we examined cell viability in response to verocytotoxin. As shown in Figure 7B, NCI/ADR-RES/ asGCS cells were substantially resistant, while NCI/ADRRES/GCS cells were extremely sensitive to verocytotoxin. 
A

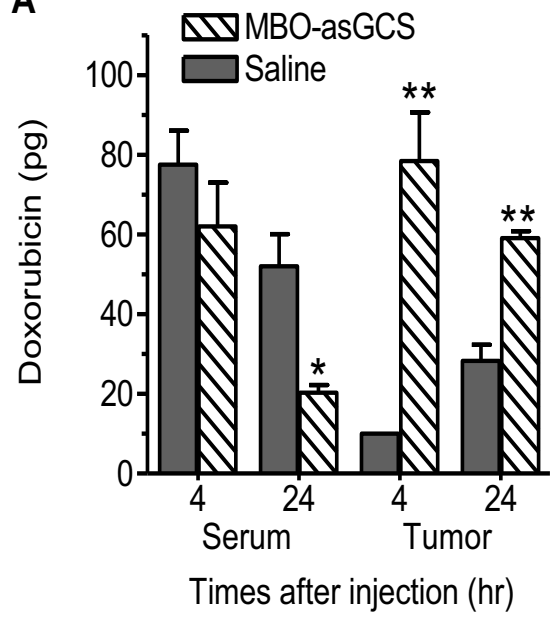

B

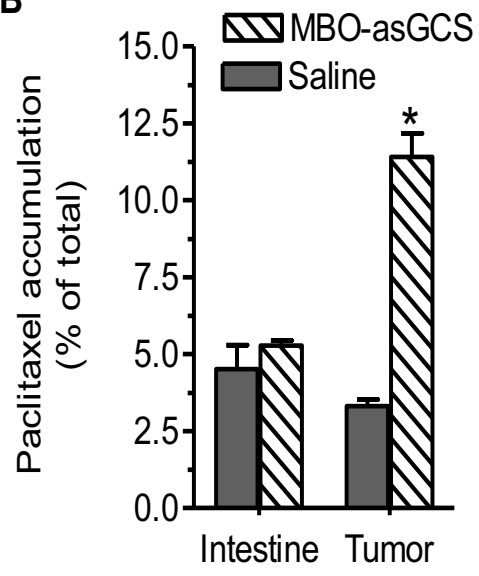

C

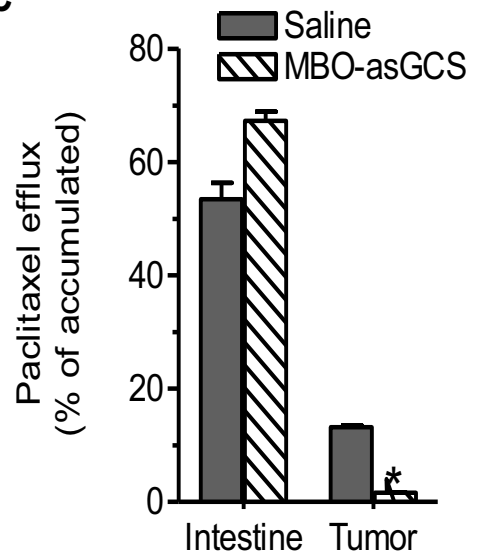

Figure 4 Effects of GCS Silencing on P-gp Regulated Drug Accumulation and Efflux in Tumors. NCI/ADR-RES tumors were treated with MBOasGCS (1 mg/kg/3 days, 3 mice/group) or saline for 7 days. (A) Doxorubicin accumulation. After $4 \mathrm{hr}$ and $24 \mathrm{hr}$ peritoneal administration of doxorubicin $(1 \mathrm{mg} / \mathrm{kg})$, serum and tumor tissues were collected and prepared for HPLC assays. Doxorubicin levels were represented per $\mu \mathrm{l}$ of serum or per mg of tumor tissue. ${ }^{*}, \mathrm{p}<0.001$ compared with serum of saline treatment at $24 \mathrm{hr} ;{ }^{*}{ }^{*}, \mathrm{P}<0.001$ compared with saline treatments. (B) Paclitaxel accumulation. After two administrations of MBO-asGCS, tissue suspensions ( $25 \mathrm{mg} /$ reaction) were incubated with Flutax-2 $(1 \mu \mathrm{M})$ in medium containing collagenase IV, immediately following mincing. Accumulation of paclitaxel was measured after $2 \mathrm{hr}$ incubation. ${ }^{*}, \mathrm{p}<0.001$ compared with saline treatment of tumors. (C) Paclitaxel efflux. After accumulation described in (B), tissues were incubated with fresh medium for an additional $2 \mathrm{hr}$ to measure paclitaxel efflux. *, $p<0.001$ compared with saline treatment of tumors.

The $\mathrm{EC}_{50}$ for verocytotoxin was increased by 4,000 -fold ( 8 $\left.\times 10^{2} v s .2 \times 10^{-1} \mathrm{ng} / \mathrm{ml}\right)$ in NCI/ADR-RES/asGCS cells and was decreased by 400 -fold $\left(2 \times 10^{-1}\right.$ vs. $\left.5 \times 10^{-4} \mathrm{ng} / \mathrm{ml}\right)$ in NCI/ADR-RES/GCS cells.

Furthermore, we examined whether GCS alter Gb3 concentration and cSrc kinase in GEMs. As shown in Figure 7C and 7D, silencing of GCS by MBO-asGCS (100 nM) significantly decreased Gb3 level, and p-cSrc to $32 \%$ in GEMs of NCI/ADR-RES cells. On the contrary, GCS transfection significantly increased Gb3 and doubled p-cSrc in GEMs of OVCAR-8 cells. Alterations of Gb3 and cSrc kinase in GEMs following GCS gene manipulations significantly changed P-gp expression levels as well.

In order to characterize the role of GSLs in MDRI expression, we selectively silenced the enzyme responsible for the synthesis of globo series GSLs. Cells were transfected with siRNA against Gb3 synthase to block globo series GSL production. As shown in Figure 8A, silencing Gb3 synthase significantly decreased MDRI promoter activity, particularly in NCI/ADR-RES/GCS cells ( $\mathrm{p}<$ 0.001, compared with NCI/ADR-RES cells). Consistently, silencing of Gb3 synthase considerably decreased p-cSrc, $\beta$-catenin and P-gp protein levels and efflux in both cell lines, as detected in Western blot (Figure 8B), cellular efflux (Figure 8C) and immunostaining (Figure 8D). We further treated NCI/ADR-RES cells with FH535, inhibiting $\beta$-catenin recruitment to T-cell factor (Tcf) [45]. We found that FH535 $(20 \mu \mathrm{M})$ decreased P-gp protein to $25 \%$ of con- trol (Figure 8E); however, it did not affect either Gb3 synthase or p-cSrc in Western blotting.

\section{Discussion}

GCS is a key enzyme for ceramide glycosylation and GSL synthesis. This study demonstrates that GCS upregulates $M D R 1$ expression and modulates drug resistance of cancer. It reveals that GSLs, in particular globo series GSLs mediate gene expression through $c S r c$ and $\beta$-catenin signaling.

Previous works indicate that GCS and MDRI are cooverexpressed in drug-resistant leukemia [33] and in drugresistant cancer cells including human ovarian cancer $(\mathrm{NCI} /$ ADR-RES), cervical cancer (KB-V1), leukemia (HL-60/ VCR), melanoma (MeWo Eto) and colon cancer (SW620/ AD) $[13,28]$. However, it is not clear how GCS or MDR1 affects each other to promote drug-resistance. Suppressing GCS with siRNA or a GCS inhibitor, 1-phenyl-2decanoylamino-3-morpholino-1-propanol (PDMP), downregulates the expression and function of $\mathrm{P}$-gp in human breast cancer cells [18]; however, inhibition of GCS by other types of GCS inhibitors (N-butyl-deoxygalactonojirimycin, OGB-1; N-nonyl-deoxygalactonojirimycin, OGB2) did not appear to have any effect on P-gp functional activity in chronic lymphocytic leukemia cells, even though OGB-1 and OGB2 sensitized these cells [46]. P-pg has been proposed as a Golgi glucosylceramide flippase that enhances neutral GSL synthesis, since transfection of $M D R 1$ increases globo series GSLs, and inhibition of P-gp 


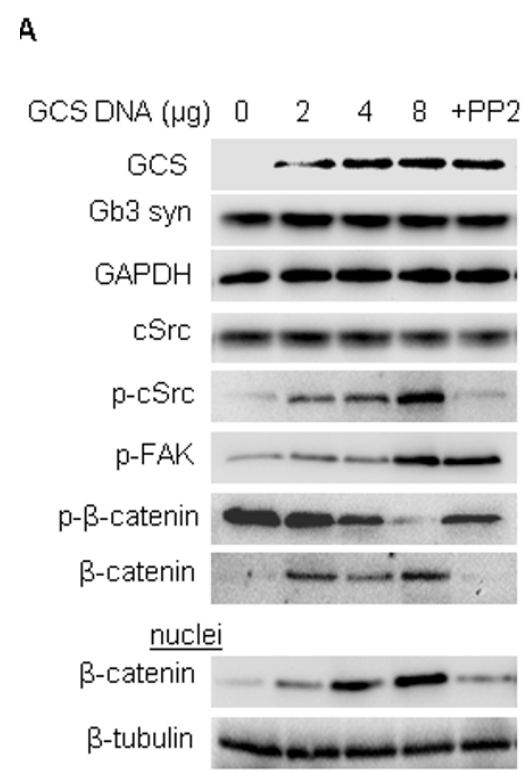

B
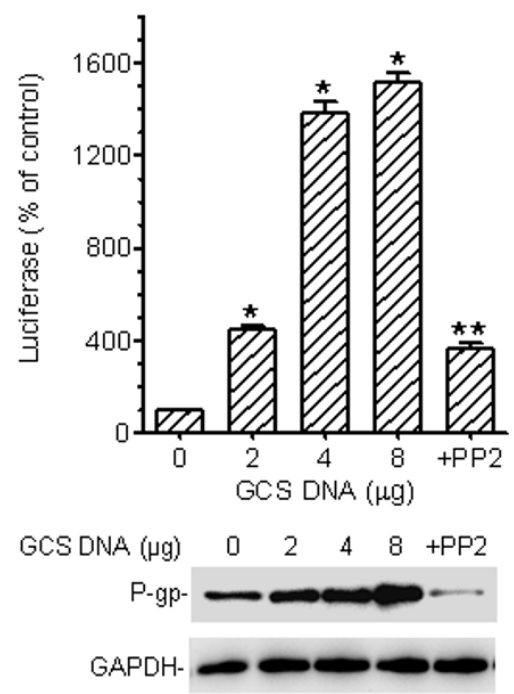

$\mathrm{C}$
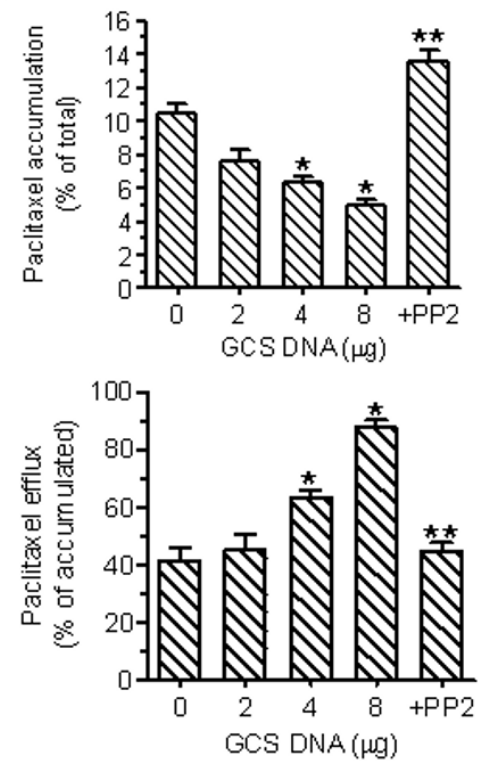

Figure 5 GCS Upregulates MDR1 Expression through Enhanced cSrc/ $\beta$-Catenin Signaling. After a series of transient GCS transfection (0, 2.0, 4.0, $8.0 \mu \mathrm{g}$ of pcDNA 3.1-GCS plasmid DNA in 100-mm dish), OVCAR-8 cells were cultured in 10\% FBS RPMI-1640 medium for 7 days. OVCAR-8 cells transfected with pCDNA 3.1-GCS (8 $\mu \mathrm{g})$ were then treated with $10 \mu \mathrm{M} \mathrm{PP2}$ for $24 \mathrm{hr}$ (+PP2). (A) Western blots. Equal amounts of detergent-soluble total cellular proteins or nuclear proteins (50 $\mathrm{\mu g} / \mathrm{lane}$ ) were resolved on 4-20\% gradient SDS-PAGE and immunoblotted with indicated primary antibodies. Gb3 syn, Gb3 synthase; p-cSrc, phosphorylated CSrc; p-FAK, phosphorylated FAK; p- $\beta$-catenin, phosphorylated $\beta$-catenin. (B) MDR1 expression. MDR1 promoter activity (top panel) and P-gp protein (bottom panel) were assessed as described in Methods, after 7 days of GCS transient transfection in OVCAR-8 cells. ${ }^{*}, p<0.001$ compared with mock transfection; ${ }^{* *}, p<0.001$ compared with vehicle treatment in cells transfected with GCS (8 $\mu \mathrm{g}$ DNA). (C) Paclitaxel accumulation and efflux. Cells were incubated with Flutax-2 $(0.5 \mu \mathrm{M})$ in medium at $37^{\circ} \mathrm{C}$. Accumulation of paclitaxel (top panel) was measured after $2 \mathrm{hr}$ incubation. After washing with ice-cold PBS, cells were re-incubated with fresh medium for an additional 2 hr to measure efflux (bottom panel). ${ }^{*}, \mathrm{p}<0.001$ compared with the mock transfection. ${ }^{* *}, \mathrm{p}<0.001$ compared with vehicle treatment in cells transfected with GCS (8 $\mu \mathrm{g}$ DNA).

with cyclosporine A decreases neutral GSL biosynthesis in cells $[32,44,47,48]$. To characterize the role of GCS in MDR1-GCS co-overexpression, we tested P-gp expression after GCS gene silencing in several different types of cancer cells and in tumors. We have found that silencing of the GCS down-regulates P-gp expression, inhibits its efflux activity, and consequently sensitizes MDR cells including NCI/ADR-RES, A2780-AD, KB-A1, SW620/AD and EMT6/AR1 (Figure 1, 2). Furthermore, suppressing GCS with MBO-asGCS substantially decreases P-gp protein, enhances the accumulation of doxorubicin or paclitaxel, and sensitizes tumors to chemotherapy (Figure 3, 4). We have reported that doxorubicin upregulates GCS expression and results in drug resistance in cells [17]. Herein it has been found that doxorubicin treatment up-regulates GCS expression and importantly, P-gp expression in tumors (Dox vs. saline, Figure 3B); MBO-asGCS simultaneously suppresses GCS and MDRl overexpression (MBO-asGCS $v s$. saline, Figure $3 \mathrm{~B}$ ), even under doxorubicin challenge (MBO-asGCS + Dox vs. Dox, Figure 3B). Taken together, these results demonstrate that GCS has a regulatory role in $M D R 1$ expression and genesis of drug resistance. Inhibition of GCS appears to be an efficient approach not only to pre- vent the formation of drug resistance during the course of cancer chemotherapy, but also to reverse drug resistance of cancers.

It has taken time to understand how GSLs generated by GCS modulate gene expression. By introducing GCS into OVCAR-8 cells that express low levels of GCS and P-gp, we have found that GCS consequently upregulates $M D R 1$ expression and enhances P-gp efflux through cSrc and $\beta$ catenin signaling. Inhibition of Src kinase by PP2 further indicates that GSLs in cell membrane may mediate the phosphorylation of $\mathrm{cSrc}$ and of $\beta$-catenin that decreases $\beta$ catenin levels in the nucleus (Figure 5). This finding has been confirmed by selective silencing of GCS (not Gb3 synthase or GD3 synthase) using MBO-asGCS, in NCI/ ADR-RES cells that over express GCS and P-gp (Figure 6). The promoter of the human MDRI contains multiple Tcf4/ LEF (T-cell factor 4/lymphoid enhancer factor) binding motifs, CTTTGA/TA/T $[49,50]$. It has been demonstrated that MDRI is a direct target gene of the $\beta$-catenin/Tcf4 transcriptional complex, and activation of $\beta$-catenin increases P-gp expression [51-53]. It has been reported that active cSrc elevates the levels of $\beta$-catenin, and inhibition of $\mathrm{cSrc}$ decreases the binding of $\beta$-catenin to the promoters of $\beta$ - 


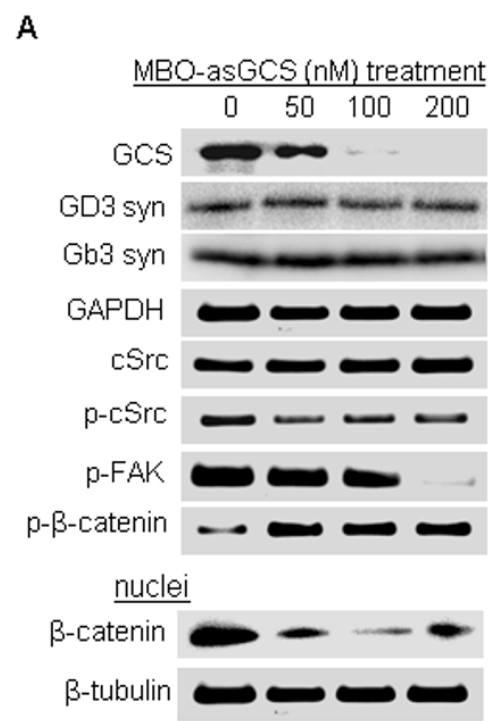

B
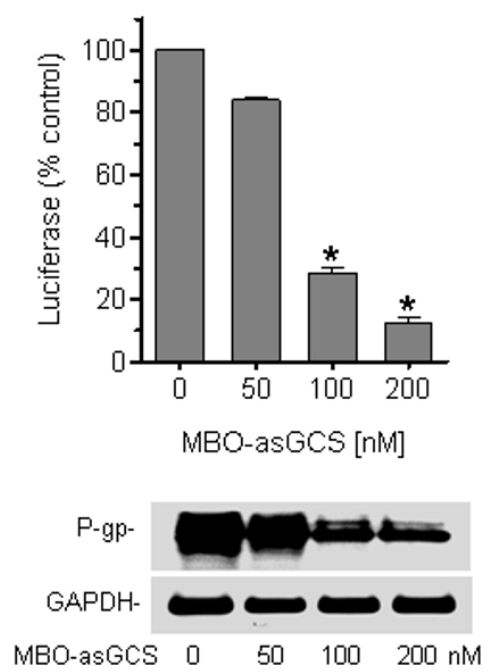

$\mathrm{C}$
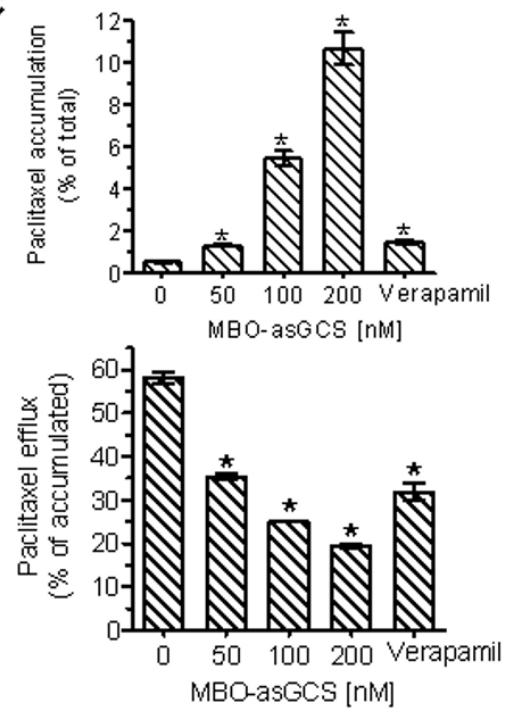

Figure 6 Silencing GCS Represses MDR1 Expression by Decreasing cSrc/ $\beta$-Catenin Signaling. After MBO-asGCS treatments $(0,50,100,200 \mathrm{nM})$, drug resistant NCI/ADR-RES cells were cultured in 10\% FBS RPMI-1640 medium for 7 days. The NCI/ADR-RES cells were incubated with verapamil (10 $\mu \mathrm{g}, 2 \mathrm{hr}$ ) in 5\% FBS RPMI-1640 medium to inhibit P-gp function. (A) Western blots. Equal amounts of total cellular proteins or nuclear proteins (50 $\mu \mathrm{g} /$ lane) were resolved by 4-20\% gradient SDS-PAGE and immunoblotted with indicated primary antibodies. GD3 syn, GD3 synthase; Gb3 syn, Gb3 synthase; p-cSrc, phosphorylated cSrc; p-FAK, phosphorylated FAK; $p$ - $\beta$-catenin, phosphorylated $\beta$-catenin. (B) MDR1 expression. MDR1 promoter activity (top panel) and P-gp protein (bottom panel) were assessed as described in Methods, after 7 days of MBO-asGCS treatments. *, $p<0.001$ compared with vehicle. (C) Paclitaxel accumulation and efflux. Cells were incubated with Flutax-2 $(0.5 \mu \mathrm{M})$ in medium at $37^{\circ} \mathrm{C}$ for $2 \mathrm{hr}$ to measure paclitaxel accumulation (top panel). After washing with ice-cold PBS, cells were incubated with fresh medium for an additional $2 \mathrm{hr}$ to measure paclitaxel efflux (bottom panel). *, $p<0.001$ compared with vehicle treatment.

catenin/Tcf4 complex targets such as cyclin D1 and c-Myc $[54,55]$. In present study, inhibitions of cSrc kinase by PP2 and $\beta$-catenin/Tcf4 recruitment by FH535 sequentially prevent MDR1 transactivation (Figure 5, 6, 8). These data strongly support the model that GCS enhances cSrc signaling and $\beta$-catenin, and transactivates MDR1 expression.

GCS is the rate-limiting enzyme in GSL synthesis. Glucosylceramide, the product of GCS, is further converted to lactosylceramide (Gal $\beta 1-4 \mathrm{GlcCer}$ ) by lactosylceramide synthase (glucosylceramide 1,4-galactosyltransferase). Lactosylceramide is the common precursor of nearly all the neutral GSLs and gangliosides. GSL profiling and selective silencing of Gb3 synthase indicate that globo series GSLs (Gb3, Gb4) have more important role than ganglioside in mediating MDR1 transactivation and expression (Figure 7, 8). GSLs in either tumor cells or normal cells are clustered and assembled with specific membrane proteins and signal transducers to form GSL-enriched microdomains (GEMs) or rafts [39,56,57]. Gb3 (defined as CD77) is associated with Src family Yes kinase on GEMs [58]. Shiga toxin binds to its receptor $\mathrm{Gb3}$, and activates cSrc kinase $[59,60]$. Stimulation of monosialyl-Gb5 by its antibody RM1 activates $\mathrm{cSrc}$ on GEMs and increases $\beta$-catenin in MCF- 7 cells [39]. AdamantylGb3, a water-soluble Gb3 mimic significantly increases $M D R 1$ expression [61]. Inhibition of GCS by D-PDMP indicates Globo series of GSLs are required for Src kinases that are associated with and concentrated on GEMs [62]. In this study we have found that introduction of GCS or silencing of GCS significantly increases or decreases the levels of $\mathrm{Gb} 3$ in entire cells, and particular in GEMs (Figure 7A,B,C). Gb3 levels affect cSrc kinase and result in p-cSrc alterations in GEMs, and consequentially Pgp expression (Figure 7). Taken together, we propose that GCS regulates $M D R 1$ expression through activation of $\mathrm{cSrc}$ and $\beta$-catenin signaling, as depicted in Figure 9. Overexpression of GCS produces large amounts of glucosylceramide when cancer cells are under chemotherapy stress. Enhancement of globo series GSLs (Gb3, Gb5, MSGb5) on the GEMs activates cSrc kinase and $\beta$-catenin signaling; nuclear $\beta$-catenin with Tcf4 binds to the MDR1 promoter and upregulates $M D R 1$ expression. Increase of $\mathrm{P}$-gp extrudes anticancer drug out of cells and leads to cancer resistance. Conversely, MBO-asGCS silences GCS gene and down-regulates P-gp through decreasing $\mathrm{cSrc}$ and $\beta$ catenin signaling.

\section{Conclusions}

This study demonstrates, for the first time, that GCS upregulates $M D R 1$ expression and modulates drug resistance of cancer. GSLs, in particular of globo series GSLs mediate 
A

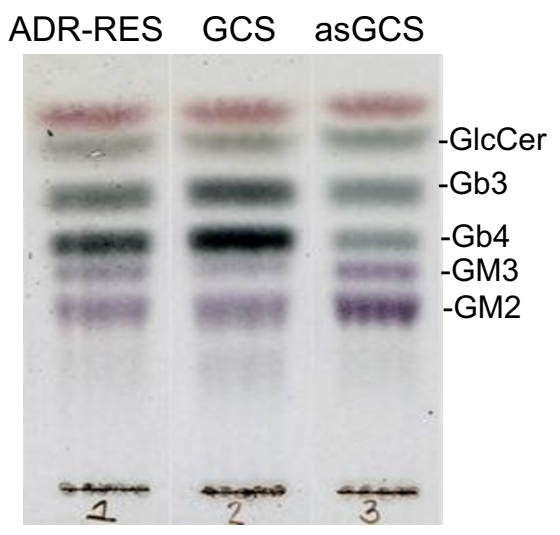

C

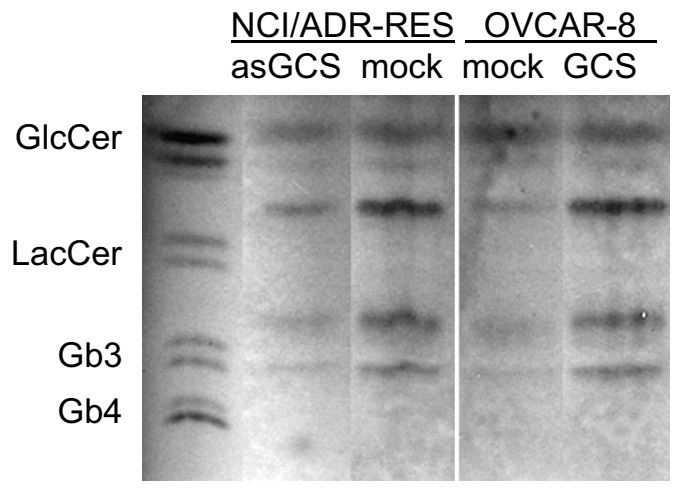

B

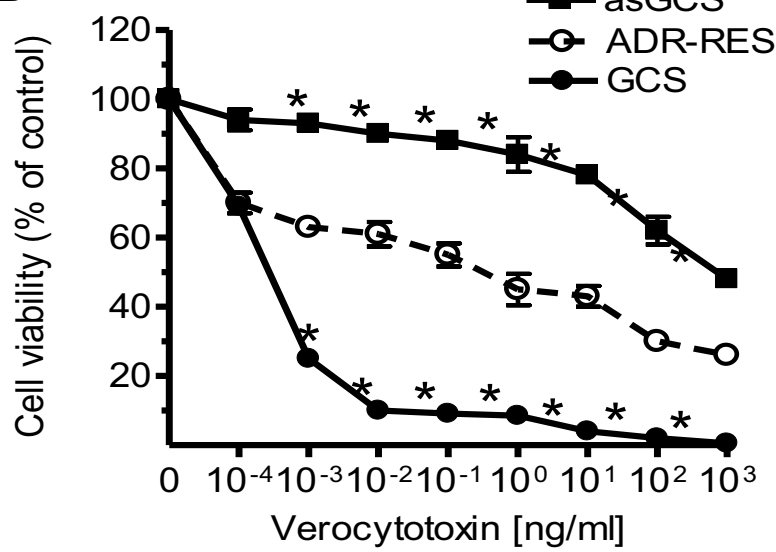

D

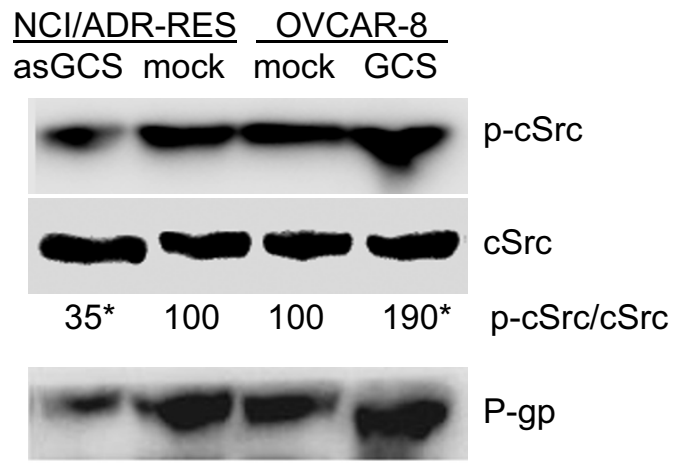

Figure 7 Globo Series GSLs Mediate MDR1 Transactivation. (A) Glycosphingolipids. Cells were cultured in 10\% FBS RPMI-1640 medium and harvested by trypsin-EDTA. Extracted lipids ( $5 \mu$ l aliquot of $100 \mu$ l) were resolve by TLC and GSLs were visualized by spraying with diphenylamine-aniline phosphoric acid reagent. GlcCer, glucosylceramide. (B) Gb3, a receptor of verocytotoxin on GCS transfectants. Cells were incubated with increasing concentrations of verocytotoxin in 5\% FBS RPMI-1640 medium for 72 hr. *, $p<0.001$ compared to ADR-RES. (C) GEM GSLs. GEMs of cells were prepared with gradient sucrose and extracted lipids (100 $\mathrm{\mu g}$ of GEM protein) were applied to HPTLC plates. (D) CSrc phosphorylation in GEMs. Equal amounts of GEM protein (50 $\mathrm{\mu g} / \mathrm{lane}$ ) were resolved by 4-12\% gradient SDS-PAGE and immunoblotted with antibodies. p-cSRc/cSrc represents optical densities of the bands; ${ }^{*}, p<0.001$ compared with mock.

gene expression of MDRl through $c S r c$ and $\beta$-catenin signaling.

\section{Methods \\ Cell culture}

Drug-resistant NCI/ADR-RES human ovarian cancer cells (designed as MCF-7-AdrR previously) $[63,64]$ were kindly provided by Dr. Kenneth Cowan (UNMC Eppley Cancer Center, Omaha, NE) and Dr. Merrill Goldsmith (National Cancer Institute, Bethesda, MD, USA). The ovarian carcinoma cells A2780-AD, which is resistant to doxorubicin [65], was kindly provided by Dr. Thomas C. Hamilton (Fox Chase Cancer Center, Philadelphia, PA). Doxorubicinselected KB-A1 cells [66] were from Dr. Michael M. Gottesman (National Cancer Institute, Bethesda, MD). Drug resistant SW620/Ad colon cancer cells [67] were kindly provided by Drs. Susan Bates and Antonio Fojo (National
Cancer Institute, Bethesda, MD). Drug-resistant murine EMT6/AR1 breast carcinoma cells $[68,69]$ were kindly provided by Dr. Ian Tannock (Ontario Cancer Institute, Toronto, ON, Canada). The OVCAR-8 human ovarian carcinoma cells were provided by Dr. M. Hollingshead of Division of Cancer Treatment and Diagnosis Tumor Repository at National Cancer Institute (Frederick, MD). NCI/ ADR-RES, KB-A1 and SW620Ad cells were maintained in RPMI-1640 medium containing 10\% (v/v) FBS, 100 units/ $\mathrm{ml}$ penicillin, $100 \mu \mathrm{g} / \mathrm{ml}$ streptomycin, and $584 \mathrm{mg} /$ liter Lglutamine. A2780-AD cells were cultured in RPMI-1640 medium containing $100 \mathrm{nM}$ doxorubicin in addition to the above components. EMT6/AR1 cells were maintained in Dulbecco's modified eagle medium (DMEM) containing 1 $\mu \mathrm{g} / \mathrm{ml}$ of doxorubicin for 2 days/week in addition to the above components. Cells were cultured in a humidified incubator with $95 \%$ air and $5 \% \mathrm{CO}_{2}$ at $37^{\circ} \mathrm{C}$. Doxorubicin 


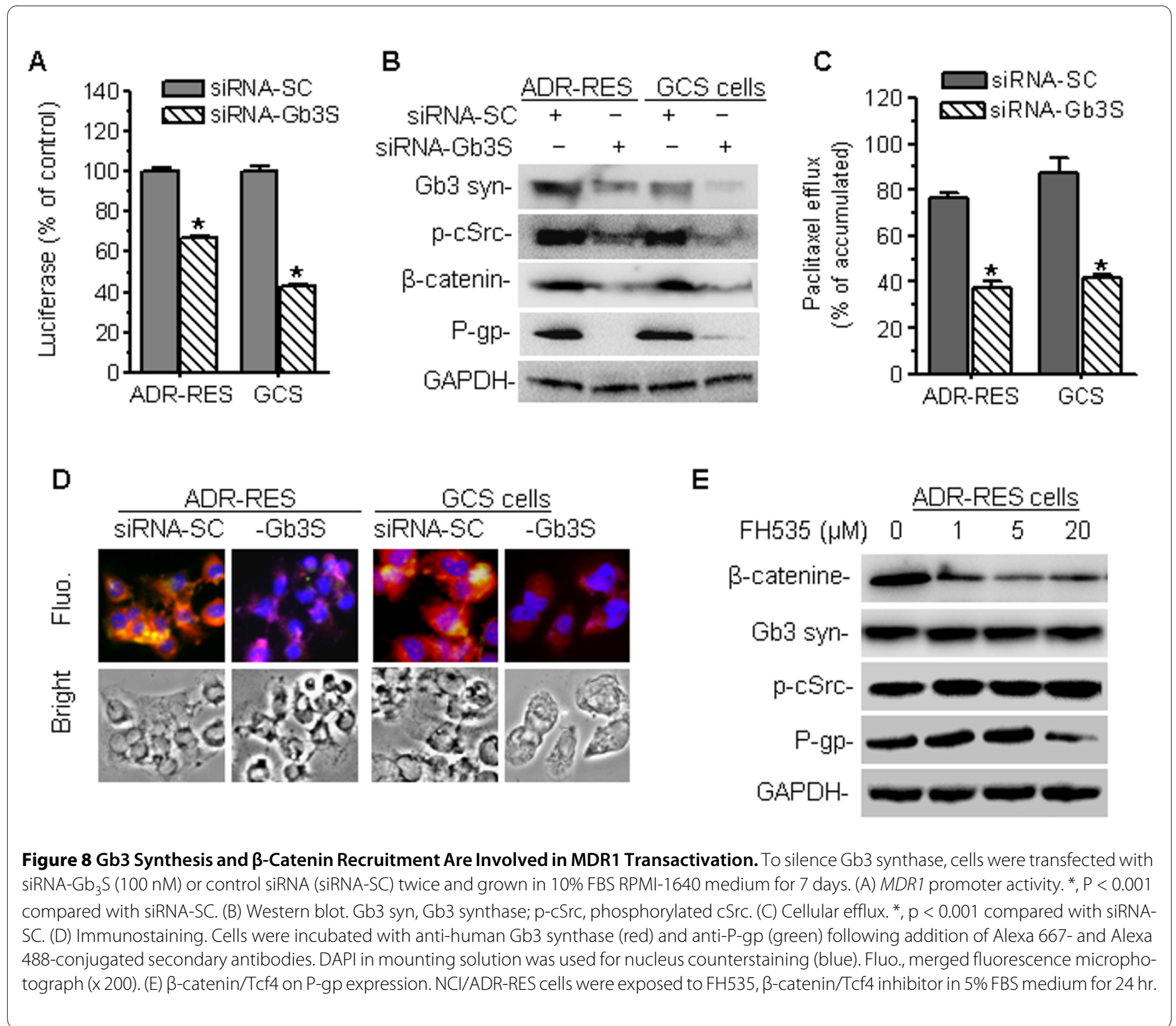

hydrochloride was purchased from Sigma (St. Luis, MO). NCI/ADR-RES cells transfected with human GCS gene (NCI/ADR-RES/GCS) and GCS antisense (NCI/ADRRES/asGCS) were cultured in RPMI 1640 containing the above components and G418 $(400 \mu \mathrm{g} / \mathrm{mL})[13,70]$.

\section{Mixed-backbone oligonucleotide and inhibitors}

A mixed-backbone oligonucleotide, designed to target the ORF 18-37 of human GCS [34,71], was verified and designated as MBO-asGCS [35]. MBO-asGCS were 20-mer phosphorothioate DNAs, except that four bases at the $5^{\prime}$ end and the 3' end were replaced by 2'-O-methyl RNA. MBOasGCS was synthesized and purified by reverse-phase HPLC and desalting (Integrated DNA Technologies, Inc., Coralville, IA). The MBO-asGCS was introduced into cells with Lipofectamine ${ }^{\mathrm{TM}} 2000$ (Invitrogen, Carlsbad, CA) in Opti-MEM I reduced-serum medium (Invitrogen). To repress $M D R 1$ expression, cells were transfected with
MBO-asGCS (100 nM) twice and grown in 10\% FBS RPMI-1640 medium for 7 days. To inhibit P-gp function, NCI/ADR-RES cells were exposed to verapamil $(10 \mu \mathrm{M})$ in $5 \%$ RPMI- 1640 at $37^{\circ} \mathrm{C}$ for $2 \mathrm{hr}$, before the analysis of accumulation and efflux. Verapamil hydrochloride was purchased from Sigma-Aldrich (St. Louis, MO).

To silence Gb3 synthase, NCI/ADR-RES and NCI/ADRRES/GCS cells were transfected with siRNA targeting human $\mathrm{Gb} 3$ synthase ( $\mathrm{siRNA}-\mathrm{Gb}_{3} \mathrm{~S} 100 \mathrm{nM}$ ) or scrambled control siRNA (siRNA-SC $100 \mathrm{nM}$ ) twice and grown in 10\% FBS RPMI-1640 medium for 7 days. The siRNA targeting human Gb3 synthase and control siRNA-A were purchased from Santa Cruz Biotechnology (Santa Cruz, CA, USA). $\beta-1,3-G a 1-T L$ siRNA (sc-62006) was designed to knockdown human $\beta$-1,3-galactosyltransferase (GeneID: 145173). Control siRNA-A was consists of a scrambled sequence that will not lead to the specific degradation of 


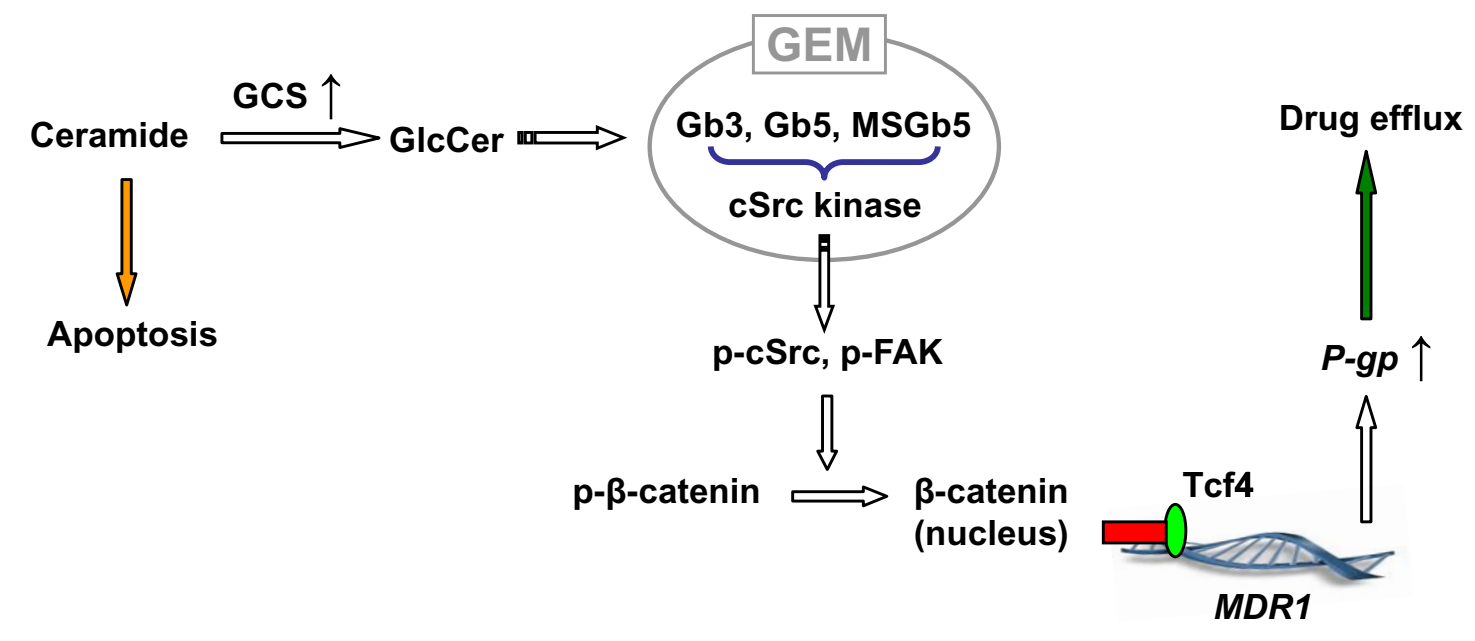

Figure 9 GSL Synthesis and MDR1 Expression. GCS, glucosylceramide synthase; GlcCer, glucosylceramide; Tcf4, T-cell factor 4; FAK, focal adhesion kinase; cSrc, proto-oncogene (Schmidt-Ruppin A-2); Gb3, globotriaosylceramide; Gb5, globopentaosylceramide; MSGb5, monosyl-Gb5.

Gb3. siRNAs $(100 \mathrm{nM})$ were introduced into these cells with Lipofectamine 2000.

A Src kinase inhibitor, 4-amino-5-(4-chlorophenyl)-7-(tbutyl) pyrazolo[3,4- $d]$ pyrimidine (PP2) [37,38] was purchased from Enzo Life Sciences (Plymouth Meeting, PA). An effective $\beta$-catenin/Tcf inhibitor, FH535 [45] was purchased from Sigma-Aldrich (St. Louis, MO). OVCAR-8/ GCS cells were incubated with PP2 $(10 \mu \mathrm{M})$ in 5\% RPMI1640 medium for $24 \mathrm{hr}$. NCI-ADR-RES cells were exposed to FH535 (1 to $20 \mu \mathrm{M})$ in 5\% RPMI-1640 medium for 24 hr.

\section{Western blotting analysis}

Western blotting was conducted as described previously $[13,17]$. After treatments, cells or tissue homogenates were lysed using NP40 cell lysis buffer (Biosource, Camarillo, CA, US) to extract the total cellular protein for Western blot. The nuclear proteins were extracted as described previously [72]. Briefly, cells were suspended in $100 \mu \mathrm{l}$ of Tween-20 lysis buffer (25 mM Tris/Hepes, $\mathrm{pH} 8.0,250 \mathrm{mM}$ $\mathrm{NaCl}, 2 \mathrm{mM}$ EDTA, $1 \mathrm{mM}$ phenylmethylsulfonyl fluoride, $0.5 \%$ Tween-20), and kept on ice for $15 \mathrm{~min}$. The nuclei were pelleted at $6000 \mathrm{~g}$ for $5 \mathrm{~min}$ at $4^{\circ} \mathrm{C}$, and then resuspended in $100 \mu \mathrm{l}$ of the lysis buffer containing $500 \mathrm{mM}$ $\mathrm{NaCl}$ and incubated on ice for additional $15 \mathrm{~min}$. After incubation, the samples were mixed with $100 \mu$ of the lysis buffer (without $\mathrm{NaCl}$ ). The supernants were collected for Western blotting following a spin-down at 10,000 $\mathrm{g}$ for 15 min. Equal amounts of these proteins $(50 \mu \mathrm{g} /$ lane $)$ were resolved using 4-20\% gradient SDS-PAGE (Invitrogen). The transferred blot was blocked with 5\% fat-free milk in PBS and immuno-blotted with primary antibodies (antiGCS goat IgG, anti-P-pg mouse, cSrc, phosphorylated cSrc, phosphorylated FAK, $\beta$-catenin, phosphorylated $\beta$-catenin) at $4{ }^{\circ} \mathrm{C}$, overnight. The antigen-antibody in blots was detected by using a second antibody-conjugated HRP and enzyme-linked chemiluminescence plus substrate (GE Healthcare). GAPDH or $\beta$-tubulin was used as loading control for total proteins or nuclear proteins.

\section{Immunohistochemistry}

Cells (10,000 cells/chamber) were grown in 4-chamber slides with $10 \%$ FBS culture medium for $48 \mathrm{hr}$. After methanol fixation, cells were blocked and then incubated with anti-GCS serum and anti-P-gp antibody (1:100) in block solution (Vector Laboratories, Burlingame, CA), overnight at $4{ }^{\circ} \mathrm{C}$. GCS antibody and P-gp antibody on cells were recognized by Alexa Fluor ${ }^{\circledR} 488$ goat anti-rabbit IgG and Alexa Fluor 667 goat anti-mouse IgG (Invitrogen). Cell nuclei were counterstained with DAPI (4', 6 diamidino-2-phenylindole) in mounting solution (Vector Laboratories). The slides were observed using a Nikon TE-2000 phase contrast microscope, and the images were captured by a Retiga $2300^{\mathrm{TM}}$ monochrome digital camera using IPLab ${ }^{\mathrm{TM}}$ image analysis program (Scanalytics Inc., Rockville, MD).

\section{Cell viability assay}

Cell viability was analyzed by quantitation of ATP, an indicator of active cells using CellTiter-Glo luminescent cell viability assay (Promega, Madison, WI), as described previously [17]. Briefly, cells (4,000 cells/well) were grown in 96-well plates with 10\% FBS RPMI-1640 medium for 24 hr. MBO-asGCS $(50 \mathrm{nM})$ was introduced into cells by Lipofectamine 2000 (vehicle) in Opti-MEM reduced-serum medium, for $4 \mathrm{hr}$. Cells were then incubated with increasing concentrations of agents in 5\% FBS medium for another 72 hr. Cell viability was determined by the measurement of 
luminescent ATP using a Synergy HT microplate reader (BioTek, Winnooski, VT. USA), following incubation with CellTiter-Glo reagent (Promega, Madison, WI, USA).

Verocytotoxin was kindly provided by Dr. Clifford A. Lingwood (University of Toronto and Hospital for Sick Children, Toronto, Canada). After $24 \mathrm{hr}$ growth in 96-well plates, cells were incubated with verocytotoxin in 5\% FBS RPMI-1640 medium for an additional $72 \mathrm{hr}$.

\section{Cellular ceramide glycosylation assay}

Cells were grown $24 \mathrm{hr}$ in $35-\mathrm{mm}$ dishes $\left(1 \times 10^{6}\right.$ cells/dish $)$ in 10\% FBS RPMI-1640 medium and MBO-asGCS (50 $\mathrm{nM}$ ) was introduced as described above. After $12 \mathrm{hr}$ growth in $10 \%$ RPMI-1640 medium, cells were switched to $1 \%$ bovine serum albumin (fatty acid free) medium containing $50 \mu \mathrm{M} \mathrm{NBD} \mathrm{C} 6_{6}$-ceramide complexed to BSA (Invitrogen). After $2 \mathrm{hr}$ incubation at $37^{\circ} \mathrm{C}$, lipids were extracted, and resolved on partisil high performance TLC plates with fluorescent indicator in a solvent system containing chloroform/ methanol/3.5 $\mathrm{N}$ ammonium hydroxide (85:15:1, v/v/v), as described previously $[17,73]$. NBD $\mathrm{C}_{6}$-glucosylceramide and $\mathrm{NBD}_{6}$-ceramide were identified using AlphaImager HP imaging system (Alpha Innotech, San Leandro, CA) and quantitated on a Synergy HT multi-detection microplate reader (BioTek). For quantitation, calibration curves were established after TLC separation of $\mathrm{NBD} \mathrm{C}_{6}$ ceramide (Invitrogen) and $\mathrm{NBD} \mathrm{C}_{6}$-glucosylceramide ( $\mathrm{N}$ hexanol-NBD-glucosylceramide; Matreya, Pleasant Gap, PA).

\section{Glycosphingolipid analysis}

Cells were cultured in 10\% FBS RPMI-1640 medium and harvested by trypsin-EDTA. Approximately $400 \mathrm{mg}$ of pelleted cells was lyophilized and extracted twice with $4 \mathrm{ml}$ of chloroform/methanol $(2 / 1, \mathrm{v} / \mathrm{v})$. The two extracts were combined, evaporated to dryness and subjected to saponification by suspending the residue in $1 \mathrm{ml}$ of $0.5 \mathrm{~N} \mathrm{NaOH}$. After incubation at $55^{\circ} \mathrm{C}$ for $1 \mathrm{hr}$, the mixture was neutralized with glacial acetic acid, evaporated to dryness, suspended in $1 \mathrm{ml}$ of water, exhaustively dialyzed against water and lyophilized. The lyophilized powder was dissolved in $100 \mu \mathrm{l}$ chloroform/methanol (2/1) and a 5- $\mu$ l aliquot was spotted on a TLC plate (Merck, Darmstadt, Germany). The plate was developed in chloroform/metha$\mathrm{nol} / 12 \mathrm{mM} \mathrm{MgCl}_{2}(50 / 40 / 10, \mathrm{v} / \mathrm{v} / \mathrm{v})$, and GSLs were visualized by spraying the plate with diphenylamine-aniline phosphoric acid reagent as described previously [74].

GSLs on GEMs were prepared and analyzed in $\mathrm{NCI} /$ ADR-RES/asGCS, OVCAR-8/GCS and each mock-transfected cell lines, as described previously $[58,75]$ with modification. Briefly, cells $\left(1 \times 10^{7}\right)$ were harvested, suspended in $1 \mathrm{ml}$ of lysis buffer containing $1 \%$ Triton X-100 (TX$100)$, and 75 units of Aprotinin in TNEV solution (10 mM
Tris-HCl, $\mathrm{pH} 7.5,150 \mathrm{mM} \mathrm{NaCl}, 5 \mathrm{mM}$ EDTA, $1 \mathrm{mM}$ $\mathrm{NaVO}_{4}$ ), homogenized and incubated on ice for $20 \mathrm{~min}$. Cell lysates were centrifuged for $5 \mathrm{~min}$ at $1300 \mathrm{~g}$ to remove nuclei and large cellular debris. The supernatant collected $(700 \mu \mathrm{l})$ was mixed with equal volume $(700 \mu \mathrm{l})$ of $85 \%$ sucrose (wt/vol) in TNEV solution. The diluted Triton X100 lysates were overlaid with $30 \%(6 \mathrm{ml})$ and $5 \%(3.3 \mathrm{ml})$ of sucrose TNEV solution in SW41 centrifuge tube. The samples were centrifuged for $18 \mathrm{~h}$ at $200,000 \mathrm{~g}$ at $4{ }^{\circ} \mathrm{C}$. White bands located at $\sim 5-7 \%$ sucrose were collected as GEM fraction and its protein content was determined using BCA Protein Assay Kit. The lipids were extracted with chlofrom/methanol/water $(1: 1: 1, \mathrm{v} / \mathrm{v} / \mathrm{v})$ from $200 \mu \mathrm{g}$ of GEM protein. Extracted lipids were resuspended in choloform-methanol $(1: 1, \mathrm{v} / \mathrm{v})$ and applied to partisil HPTLC plates. Lipids were resolved using the solvent system of chloroform/methanol/water $(65: 25: 4 \mathrm{v} / \mathrm{v} / \mathrm{v})$. Acid alcohol (90\% methanol $/ 5 \%$ sulfuric acid, 5\% acetic acid; SigmaAldrich) was used for the chemical detection of glycosphingolipids. Neurtral glycospingolipids qualmix and ceramide trihexosides (Gb3) were purchased from Matreya (Pleasant Gap, PA) and used as standards in TLC.

\section{High-pressure liquid chromatography (HPLC) analysis of doxorubicin}

The concentrations of doxorubicin in cells, serum and tumors were analyzed, as described previously with minor modifications [76,77]. Cells $\left(2.5 \times 10^{5}\right.$ cells/well $)$ were grown in 6-well plates with 10\% FBS RPMI-1640 medium. After $24 \mathrm{hr}$, cells were shifted to medium containing doxorubicin $(100 \mu \mathrm{M})$ for $2 \mathrm{hr}$ incubation, at $37^{\circ} \mathrm{C}$. Following ice-cold PBS rinsing, cellular doxorubicin was extracted using $3 \mathrm{ml}$ of methanol. For tumor samples, $\sim 80 \mathrm{mg}$ of tissue was homogenized in $200 \mu \mathrm{l}$ of ice-cold methanol. After centrifugation $(7,000 \mathrm{~g}, 10 \mathrm{~min})$, the supernatant of samples was injected into the HPLC system with an auto-sampler. Doxorubicin was resolved on a Pecosphere C18 reversedphase column with mobile phase of $50 \mathrm{mM}$ sodium phosphate buffer ( $\mathrm{pH} 2.0)$ :acetonitrile:1-propanol (65:25:2; v/v/ $\mathrm{v}$; flow rate of $0.8 \mathrm{ml} / \mathrm{min})$. Doxorubicin was detected with the use of a scanning fluorescence detector at $\lambda_{\text {excitation }} 480$ $\mathrm{nm}$ and $\lambda_{\text {emission }} 550 \mathrm{~nm}$. The retention time was approximately 7 minutes for doxorubicin. Standard curves were linear within the range of $1 \mathrm{ng} / \mathrm{ml}$ to $100 \mathrm{ng} / \mathrm{ml}$ (equal to $0.002 \sim 0.17 \mu \mathrm{M})$. Samples containing high doxorubicin concentrations were diluted as needed.

For the analysis of doxorubicin in serum, proteins were precipitated with $10 \%$ trichloroacetic acid. The supernatant obtained after centrifugation $(7,000 \mathrm{~g}, 10 \mathrm{~min})$ was used for HPLC assay.

\section{Paclitaxel accumulation and efflux}

The measurements were performed as described previously $[78,79]$. After treatments or transfection, cells were grown 
in 10\% FBS RPMI-1640 medium for $24 \mathrm{hr}$ and then shifted to $5 \%$ FBS RPMI-1640 medium containing Fluotax-2 (Oregon green 488 paclitaxel, $0.5 \mu \mathrm{M})$ and incubated at $37^{\circ} \mathrm{C}$ for $2 \mathrm{hr}$. After ice-cold wash and trypsinization, accumulation of paclitaxel was measured. For efflux, at the end of the $2 \mathrm{hr}$ incubation, fresh media was added following wash and re-incubated at $37^{\circ} \mathrm{C}$ for an additional $2 \mathrm{hr}$. Fluorescent paclitaxel was measured at $\lambda_{\text {excitation }} 485 \mathrm{~nm}$ and $\lambda_{\text {emission }} 529$ $\mathrm{nm}$ using a Synergy HT microplate reader. Cellular accumulation of paclitaxel was normalized to cell number and paclitaxel added (total intensity). The efflux was normalized against accumulated paclitaxel in cells. Flutax-2 (Oregon green 488 paclitaxel) was purchased from Invitrogen.

After two MBO-asGCS administrations $(1 \mathrm{mg} / \mathrm{kg}$ every 3 -days, ip, 3 mice/group), the small intestine (ileum) and tumors were resected. Tissues $(25 \mathrm{mg} /$ reaction $)$ were incubated with fluorescent paclitaxel $(1.0 \mu \mathrm{M})$ in $200 \mu \mathrm{l}$ of $1 \%$ BSA RPMI-1640 medium containing collagenase IV, immediately following mincing. Accumulation of paclitaxel was measured after $2 \mathrm{hr}$ incubation and 3 times of washes with ice-cold PBS. For efflux, samples were incubated with fresh medium for an additional $2 \mathrm{hr}$ following accumulation and washed 3 times with ice-cold PBS.

\section{Drug-resistant tumor models and treatments}

Drug-resistant NCI/ADR-RES tumors were established by using the methods described previously $[35,80]$. Athymic nude mice (Foxn $1^{n u} /$ Foxn $^{+}$, 4-5 weeks, female) were purchased from Harlan (Indianapolis, IN) and maintained in the Vivarium, University of Louisiana at Monroe, according to the approved protocol. Cultured cells after 3 to 5 passages were washed with and resuspended in serum-free RPMI-1640 medium. A suspension of NCI/ADR-RES cells $\left(1 \times 10^{6}\right.$ cells in $20 \mu \mathrm{l}$ per mouse $)$ was injected into the left flank of the mouse. The mice were monitored by measuring tumor growth, body weight and clinical observation. Tumor-bearing mice were randomly divided into multiple treatment and control groups (ten mice per group). MBOs, dissolved in RPMI 1640 medium were given at the dose of $1 \mathrm{mg} / \mathrm{kg}$, twice per week, at the tumor site. The control group received medium only. In combination therapy, doxorubicin was given by intraperitoneal injection at $2 \mathrm{mg} / \mathrm{kg}$ once a week with medium or MBOs for 42 days, respectively.

Tumors were removed, fixed and maintained in paraffin blocks. Microsections from each tumor $(5 \mu \mathrm{m})$ were $\mathrm{H} \& \mathrm{E}$ stained and identified by pathologist (Dr. J. Bao). For immunostaining, antigens were retrieved in steaming sodium citrate buffer (10 mM, 0.05\% Tween-20, $\mathrm{pH} 6.0,10$ $\mathrm{min}$ ). After blocking with $2 \%$ block solution (Vector Laboratories, Burlingame, CA), the slides were incubated with primary antibodies $(1: 100)$ at $4^{\circ} \mathrm{C}$, overnight.

\section{MDR1 promoter assay}

The human MDRI promoter reporter, pMDR1 [81] was kindly provided by Dr. Kathleen W. Scotto (University of Medicine and Dentistry of New Jersey, New Brunswick, NJ). MDR1 promoter (sequence from -1202 to +118 ) drives luciferase expression from pGL2B. After treatments or transfection, cells $\left(2.5 \times 10^{5}\right.$ cells/well $)$ were placed into 6well plates with $10 \%$ FBS RPMI-1640 medium. After $24 \mathrm{hr}$ culture, pMDR1 plasmid (4 $\mu \mathrm{g} / \mathrm{well})$ and pGL4 renilla luciferase reporter driven by thymidine kinase promoter (pGL4-hRluc/TK; $4 \mu \mathrm{g} /$ well) were introduced into cells with Lipofectamine 2000 and cells were cultured in $10 \%$ FBS medium for additional $48 \mathrm{hr}$. Cell lysates were incubated with Dual-luciferase reporter assay system reagents (Promega). The intensities of firefly luciferase (MDRl promoter activity) and renilla luciferase (TK promoter activity) were measured using a Synergy HT multidetection microplate reader. $M D R 1$ promoter activity was normalized to protein and TK promoter.

\section{Statistic analysis}

All data represent the mean \pm SD. Experiments in triplicate were repeated 2 or 3 times in cell models. Student's $t$ test was used to compare mean values, using a Prism 4 program (GraphPad software, San Diego, CA).

\section{Competing interests}

The authors declare that they have no competing interests.

\section{Authors' contributions}

YYL conceived, designed the experiments and carried out parts of Western blot, immunostaining, the generation of GCS transfectants, animal study and verocytotoxin assays; YYL further performed all data analysis, writing of the manuscript, including preparations of all figures.

VG carried out HPLC analysis of doxorubicin, ceramide glycosylation, Gb3 in GEMs, promoter activity assay, nuclear protein preparation, cell culture and GCS transfection. VG participated in data analysis, figure preparation and critical reading of the draft.

GAP carried out Western blot analysis, cell culture, animal study and P-gp efflux assay. GAP participated in data analysis, figure preparation and critical reading of the draft.

KB carried out plasmid DNA preparation and parts of promoter activity assay. YZ carried out immunostaining and critical reading of the draft

JB carried out tissue section preparation, H\&E staining and tumor characterization.

HM carried out parts of HPLC analysis of doxorubicin and critical reading of the draft.

MCC participated in parts of experimental design and critical reading of the draft.

YTL carried out glycosphingolipid assay and critical reading of the draft. SMJ participated in experimental design and critical reading of the draft. All authors read and approved the final manuscript.

\section{Acknowledgements}

This work was supported by United States Public Health Service/NIH grant P20 RR16456 from the NCRR (Y.Y.L, S.M.J), Department of Defense Breast Cancer Research Program DAMD17-01-1-0536 (Y.Y.L.). We thank Dr. Clifford A. Lingwood (University of Toronto and Hospital for Sick Children, Toronto, Canada) for providing verocytotoxin and Dr. Kathleen W. Scotto (University of Medicine and Dentistry of New Jersey, New Brunswick, NJ) for providing human MDR1 promoter reporter. 


\section{Author Details}

'Department of Basic Pharmaceutical Sciences, University of Louisiana at Monroe, Monroe, Louisiana 71209, USA, ${ }^{2}$ Department of Pharmacology, Toxicology and Neuroscience, Louisiana State University Health Sciences Center, Shreveport, Louisiana 71130, USA, ${ }^{3}$ Department of Pathology, Louisiana State University Health Sciences Center, Shreveport, Louisiana 71130, USA, ${ }^{4}$ Department of Toxicology, University of Louisiana at Monroe, Monroe, Louisiana 71209, USA, ${ }^{5}$ Department of Experimental Therapeutics, John Wayne Cancer Institute, Santa Monica, California 90404, USA, ${ }^{\circ}$ Department of Biochemistry, Tulane University School of Medicine, New Orleans, Louisiana 70112, USA and ${ }^{7}$ Department of Medicine and Tulane Center for Aging, Tulane University School of Medicine, New Orleans, Louisiana 70112, USA

Received: 11 December 2009 Accepted: 11 June 2010

Published: 11 June 2010

\section{References}

1. Harris AL, Hochhauser D: Mechanisms of multidrug resistance in cancer treatment. Acta Oncol 1992, 31:205-213.

2. Gottesman MM: Mechanisms of cancer drug resistance. Annu Rev Med 2002, 53:615-627.

3. Kimura Y, Morita SY, Matsuo M, Ueda K: Mechanism of multidrug recognition by MDR1/ABCB1. Cancer Sci 2007, 98:1303-1310.

4. Ambudkar SV, Kimchi-Sarfaty C, Sauna ZE, Gottesman MM: Pglycoprotein: from genomics to mechanism. Oncogene 2003, 22:7468-7485.

5. Ahmed FE: Molecular markers that predict response to colon cancer therapy. Expert Rev Mol Diagn 2005, 5:353-375.

6. Sarkadi B, Muller M, Hollo Z: The multidrug transporters--proteins of an ancient immune system. Immunol Lett 1996, 54:215-219.

7. Kimchi-Sarfaty C, Oh JM, Kim IW, Sauna ZE, Calcagno AM, Ambudkar SV, Gottesman MM: A "silent" polymorphism in the MDR1 gene changes substrate specificity. Science 2007, 315:525-528.

8. Mahadevan D, List AF: Targeting the multidrug resistance-1 transporter in AML: molecular regulation and therapeutic strategies. Blood 2004, 104:1940-1951.

9. McDevitt CA, Callaghan R: How can we best use structural information on P-glycoprotein to design inhibitors? Pharmacol Ther 2007, 113:429-441.

10. Leonard GD, Polgar $\mathrm{O}$, Bates $\mathrm{SE}: \mathrm{ABC}$ transporters and inhibitors: new targets, new agents. Curr Opin Investig Drugs 2002, 3:1652-1659.

11. el-Deiry WS: Role of oncogenes in resistance and killing by cancer therapeutic agents. Curr Opin Oncol 1997, 9:79-87.

12. Wojtal KA, de Vries E, Hoekstra D, van ljzendoorn SC: Efficient trafficking of MDR1/P-glycoprotein to apical canalicular plasma membranes in HepG2 cells requires PKA-Rllalpha anchoring and glucosylceramide. Mol Biol Cell 2006, 17:3638-3650.

13. Liu YY, Han TY, Giuliano AE, Cabot MC: Ceramide glycosylation potentiates cellular multidrug resistance. FASEB J 2001, 15:719-730.

14. Reynolds CP, Maurer BJ, Kolesnick RN: Ceramide synthesis and metabolism as a target for cancer therapy. Cancer Lett 2004, 206:169-180.

15. Senchenkov A, Litvak DA, Cabot MC: Targeting ceramide metabolism--a strategy for overcoming drug resistance. J Nat/ Cancer Inst 2001, 93:347-357.

16. Liu YY, Han TY, Giuliano AE, Cabot MC: Expression of glucosylceramide synthase, converting ceramide to glucosylceramide, confers adriamycin resistance in human breast cancer cells. J Biol Chem 1999, 274:1140-1146.

17. Liu YY, Yu JY, Yin D, Patwardhan GA, Gupta V, Hirabayashi Y, Holleran WM, Giuliano AE, Jazwinski SM, Gouaze-Andersson V, et al.: A role for ceramide in driving cancer cell resistance to doxorubicin. FASEB J 2008, 22:2541-2551.

18. Gouaze V, Liu YY, Prickett CS, Yu JY, Giuliano AE, Cabot MC: Glucosylceramide synthase blockade down-regulates P-glycoprotein and resensitizes multidrug-resistant breast cancer cells to anticancer drugs. Cancer Res 2005, 65:3861-3867.

19. Hannun YA: The sphingomyelin cycle and the second messenger function of ceramide. J Biol Chem 1994, 269:3125-3128.

20. Ichikawa S, Hirabayashi Y: Glucosylceramide synthase and glycosphingolipid synthesis. Trends Cell Biol 1998, 8:198-202.
21. Yamashita T, Wada R, Sasaki T, Deng C, Bierfreund U, Sandhoff K, Proia RL: A vital role for glycosphingolipid synthesis during development and differentiation. Proc Natl Acad Sci USA 1999, 96:9142-9147.

22. Kolesnick R, Altieri D, Fuks Z: A CERTain role for ceramide in taxaneinduced cell death. Cancer Cell 2007, 11:473-475.

23. Kolesnick R, Hannun YA: Ceramide and apoptosis. Trends Biochem Sci 1999, 24:224-225.

24. Ogretmen B, Hannun YA: Updates on functions of ceramide in chemotherapy-induced cell death and in multidrug resistance. Drug Resist Updat 2001, 4:368-377.

25. Kolesnick R, Fuks Z: Radiation and ceramide-induced apoptosis. Oncogene 2003, 22:5897-5906.

26. Ogretmen B, Schady D, Usta J, Wood R, Kraveka JM, Luberto C, Birbes H, Hannun YA, Obeid LM: Role of ceramide in mediating the inhibition of telomerase activity in A549 human lung adenocarcinoma cells. $J$ Biol Chem 2001, 276:24901-24910.

27. Liu YY, Han TY, Giuliano AE, Ichikawa S, Hirabayashi Y, Cabot MC: Glycosylation of ceramide potentiates cellular resistance to tumor necrosis factor-alpha-induced apoptosis. Exp Cell Res 1999, 252:464-470.

28. Gouaze V, Yu JY, Bleicher RJ, Han TY, Liu YY, Wang H, Gottesman MM, Bitterman A, Giuliano AE, Cabot MC: Overexpression of glucosylceramide synthase and P-glycoprotein in cancer cells selected for resistance to natural product chemotherapy. Mol Cancer Ther 2004, 3:633-639.

29. Jones J, Otu H, Spentzos D, Kolia S, Inan M, Beecken WD, Fellbaum C, Gu X, Joseph M, Pantuck AJ, et al:: Gene signatures of progression and metastasis in renal cell cancer. Clin Cancer Res 2005, 11:5730-5739.

30. Ruckhaberle E, Karn T, Hanker L, Gatje R, Metzler D, Holtrich U, Kaufmann M, Rody A: Prognostic relevance of glucosylceramide synthase (GCS) expression in breast cancer. J Cancer Res Clin Oncol 2009, 135:81-90.

31. Itoh M, Kitano T, Watanabe M, Kondo T, Yabu T, Taguchi Y, Iwai K, Tashima M, Uchiyama T, Okazaki T: Possible role of ceramide as an indicator of chemoresistance: decrease of the ceramide content via activation of glucosylceramide synthase and sphingomyelin synthase in chemoresistant leukemia. Clin Cancer Res 2003, 9:415-423.

32. Shabbits JA, Mayer LD: P-glycoprotein modulates ceramide-mediated sensitivity of human breast cancer cells to tubulin-binding anticancer drugs. Mol Cancer Ther 2002, 1:205-213.

33. Xie P, Shen YF, Shi YP, Ge SM, Gu ZH, Wang J, Mu HJ, Zhang B, Qiao WZ, Xie KM: Overexpression of glucosylceramide synthase in associated with multidrug resistance of leukemia cells. Leuk Res 2008, 32:475-480.

34. Liu YY, Han TY, Yu JY, Bitterman A, Le A, Giuliano AE, Cabot MC: Oligonucleotides blocking glucosylceramide synthase expression selectively reverse drug resistance in cancer cells. J Lipid Res 2004 45:933-940.

35. Patwardhan GA, Zhang QJ, Yin D, Gupta V, Bao J, Senkal CE, Ogretmen B, Cabot MC, Shah GV, Sylvester PW, et al: A new mixed-backbone oligonucleotide against glucosylceramide synthase Sensitizes multidrug-resistant tumors to apoptosis. PLoS One 2009, 4:e6938.

36. Brimacombe KR, Hall MD, Auld DS, Inglese J, Austin CP, Gottesman MM, Fung KL: A dual-fluorescence high-throughput cell line system for probing multidrug resistance. Assay Drug Dev Technol 2009, 7:233-249.

37. Maupas-Schwalm F, Robinet C, Auge N, Thiers JC, Garcia V, Cambus JP, Salvayre R, Negre-Salvayre A: Activation of the \{beta\}-catenin/T-cellspecific transcription factor/lymphoid enhancer factor-1 pathway by plasminogen activators in ECV304 carcinoma cells. Cancer Res 2005, 65:526-532.

38. Chen JK, Capdevila J, Harris RC: Overexpression of C-terminal Src kinase blocks 14, 15-epoxyeicosatrienoic acid-induced tyrosine phosphorylation and mitogenesis. J Biol Chem 2000, 275:13789-13792

39. Steelant WF, Kawakami Y, Ito A, Handa K, Bruyneel EA, Mareel M, Hakomori S: Monosialyl-Gb5 organized with cSrc and FAK in GEM of human breast carcinoma MCF-7 cells defines their invasive properties. FEBS Lett 2002, 531:93-98.

40. Van Slambrouck S, Steelant WF: Clustering of monosialyl-Gb5 initiates downstream signalling events leading to invasion of MCF-7 breast cancer cells. Biochem J 2007, 401:689-699.

41. Hitosugi T, Sato M, Sasaki K, Umezawa Y: Lipid raft specific knockdown of SRC family kinase activity inhibits cell adhesion and cell cycle progression of breast cancer cells. Cancer Res 2007, 67:8139-8148. 
42. Arab S, Murakami M, Dirks P, Boyd B, Hubbard SL, Lingwood CA, Rutka JT: Verotoxins inhibit the growth of and induce apoptosis in human astrocytoma cells. J Neurooncol 1998, 40:137-150.

43. Kiarash A, Boyd B, Lingwood CA: Glycosphingolipid receptor function is modified by fatty acid content. Verotoxin 1 and verotoxin $2 c$ preferentially recognize different globotriaosyl ceramide fatty acid homologues. J Biol Chem 1994, 269:11138-11146.

44. Lala P, Ito S, Lingwood CA: Retroviral transfection of Madin-Darby canine kidney cells with human MDR1 results in a major increase in globotriaosylceramide and 10(5)- to 10(6)-fold increased cell sensitivity to verocytotoxin. Role of p-glycoprotein in glycolipid synthesis. J Biol Chem 2000, 275:6246-6251.

45. Handeli S, Simon JA: A small-molecule inhibitor of Tcf/beta-catenin signaling down-regulates PPARgamma and PPARdelta activities. $\mathrm{Mol}$ Cancer Ther 2008, 7:521-529.

46. Gerrard G, Butters TD, Ganeshaguru K, Mehta AB: Glucosylceramide synthase inhibitors sensitise CLL cells to cytotoxic agents without reversing P-gp functional activity. Eur J Pharmacol 2009, 609:34-39.

47. De Rosa MF, Sillence D, Ackerley C, Lingwood C: Role of multiple drug resistance protein 1 in neutral but not acidic glycosphingolipid biosynthesis. J Biol Chem 2004, 279:7867-7876.

48. Morjani H, Aouali N, Belhoussine R, Veldman RJ, Levade T, Manfait M: Elevation of glucosylceramide in multidrug-resistant cancer cells and accumulation in cytoplasmic droplets. Int J Cancer 2001, 94:157-165.

49. Madden MJ, Morrow CS, Nakagawa M, Goldsmith ME, Fairchild CR, Cowan $\mathrm{KH}$ : Identification of 5 ' and 3 ' sequences involved in the regulation of transcription of the human mdr1 gene in vivo. J Biol Chem 1993, 268:8290-8297.

50. Tetsu O, McCormick F: Beta-catenin regulates expression of cyclin D1 in colon carcinoma cells. Nature 1999, 398:422-426.

51. Yamada T, Takaoka AS, Naishiro Y, Hayashi R, Maruyama K, Maesawa C, Ochiai A, Hirohashi S: Transactivation of the multidrug resistance $1 \mathrm{gene}$ by $\mathrm{T}$-cell factor 4 /beta-catenin complex in early colorectal carcinogenesis. Cancer Res 2000, 60:4761-4766.

52. Yamada T, Mori Y, Hayashi R, Takada M, Ino Y, Naishiro Y, Kondo T, Hirohashi S: Suppression of intestinal polyposis in Mdr1-deficient ApcMin/+ mice. Cancer Res 2003, 63:895-901.

53. Lim JC, Kania KD, Wijesuriya H, Chawla S, Sethi JK, Pulaski L, Romero IA, Couraud PO, Weksler BB, Hladky SB, Barrand MA: Activation of betacatenin signalling by GSK-3 inhibition increases p-glycoprotein expression in brain endothelial cells. J Neurochem 2008, 106:1855-1865.

54. Karni R, Gus Y, Dor Y, Meyuhas O, Levitzki A: Active Src elevates the expression of beta-catenin by enhancement of cap-dependent translation. Mol Cell Biol 2005, 25:5031-5039.

55. Chang YM, Bai L, Liu S, Yang JC, Kung HJ, Evans CP. Src family kinase oncogenic potential and pathways in prostate cancer as revealed by AZD0530. Oncogene 2008, 27:6365-6375.

56. Kazui A, Ono M, Handa K, Hakomori S: Glycosylation affects translocation of integrin, Src, and caveolin into or out of GEM. Biochem Biophys Res Commun 2000, 273:159-163.

57. Hakomori Si SI: Inaugural Article: The glycosynapse. Proc Natl Acad Sci USA 2002, 99:225-232.

58. Katagiri YU, Mori T, Nakajima H, Katagiri C, Taguchi T, Takeda T, Kiyokawa N, Fujimoto J: Activation of Src family kinase yes induced by Shiga toxin binding to globotriaosyl ceramide (Gb3/CD77) in low density, detergent-insoluble microdomains. J Bio/ Chem 1999, 274:35278-35282.

59. Malyukova I, Murray KF, Zhu C, Boedeker E, Kane A, Patterson K, Peterson JR, Donowitz M, Kovbasnjuk O: Macropinocytosis in Shiga toxin 1 uptake by human intestinal epithelial cells and transcellular transcytosis. Am J Physiol Gastrointest Liver Physiol 2009, 296:G78-92

60. Mori T, Kiyokawa N, Katagiri YU, Taguchi T, Suzuki T, Sekino T, Sato N, Ohmi K, Nakajima H, Takeda T, Fujimoto J: Globotriaosyl ceramide (CD77/Gb3) in the glycolipid-enriched membrane domain participates in B-cell receptor-mediated apoptosis by regulating lyn kinase activity in human B cells. Exp Hematol 2000, 28:1260-1268.

61. De Rosa MF, Ackerley C, Wang B, Ito S, Clarke DM, Lingwood C: Inhibition of multidrug resistance by adamantylgb3, a globotriaosylceramide analog. J Biol Chem 2008, 283:4501-4511.

62. Inokuchi Jl, Uemura S, Kabayama K, Igarashi Y: Glycosphingolipid deficiency affects functional microdomain formation in Lewis lung carcinoma cells. Glycoconj J 2000, 17:239-245.
63. Fairchild CR, Ivy SP, Kao-Shan CS, Whang-Peng J, Rosen N, Israel MA, Melera PW, Cowan KH, Goldsmith ME: Isolation of amplified and overexpressed DNA sequences from adriamycin-resistant human breast cancer cells. Cancer Res 1987, 47:5141-5148.

64. Mehta K, Devarajan E, Chen J, Multani A, Pathak S: Multidrug-resistant MCF-7 cells: an identity crisis? J Nat/ Cancer Inst 2002, 94:1652-1654.

65. Rogan AM, Hamilton TC, Young RC, Klecker RW Jr, Ozols RF: Reversal of adriamycin resistance by verapamil in human ovarian cancer. Science 1984, 224:994-996.

66. Akiyama S, Fojo A, Hanover JA, Pastan I, Gottesman MM: Isolation and genetic characterization of human $\mathrm{KB}$ cell lines resistant to multiple drugs. Somat Cell Mol Genet 1985, 11:117-126.

67. Lai GM, Chen YN, Mickley LA, Fojo AT, Bates SE: P-glycoprotein expression and schedule dependence of adriamycin cytotoxicity in human colon carcinoma cell lines. Int J Cancer 1991, 49:696-703.

68. Primeau AJ, Rendon A, Hedley D, Lilge L, Tannock IF: The distribution of the anticancer drug Doxorubicin in relation to blood vessels in solid tumors. Clin Cancer Res 2005, 11:8782-8788.

69. Mistry P, Stewart AJ, Dangerfield W, Okiji S, Liddle C, Bootle D, Plumb JA, Templeton D, Charlton P: In vitro and in vivo reversal of P-glycoproteinmediated multidrug resistance by a novel potent modulator, XR9576. Cancer Res 2001, 61:749-758.

70. Liu YY, Han TY, Giuliano AE, Hansen N, Cabot MC: Uncoupling ceramide glycosylation by transfection of glucosylceramide synthase antisense reverses adriamycin resistance. J Biol Chem 2000, 275:7138-7143.

71. Ichikawa S, Sakiyama H, Suzuki G, Hidari Kl, Hirabayashi Y: Expression cloning of a cDNA for human ceramide glucosyltransferase that catalyzes the first glycosylation step of glycosphingolipid synthesis. Proc Natl Acad Sci USA 1996, 93:4638-4643.

72. Klenova E, Chernukhin I, Inoue T, Shamsuddin S, Norton J: Immunoprecipitation techniques for the analysis of transcription factor complexes. Methods 2002, 26:254-259.

73. Gupta V, Patwardhan GA, Zhang QJ, Cabot MC, Jazwinski SM, Liu YY: Direct quantitative determination of ceramide glycosylation in vivo: a new approach to evaluate cellular enzyme activity of glucosylceramide synthase. J Lipid Res 2010, 51:866-874

74. Anderson K, Li SC, Li YT: Diphenylamine-aniline-phosphoric acid reagent, a versatile spray reagent for revealing glycoconjugates on thin-layer chromatography plates. Anal Biochem 2000, 287:337-339.

75. Rodgers W, Rose JK: Exclusion of CD45 inhibits activity of p56lck associated with glycolipid-enriched membrane domains. J Cell Biol 1996, 135:1515-1523.

76. Zhou Q, Chowbay B: Determination of doxorubicin and its metabolites in rat serum and bile by LC: application to preclinical pharmacokinetic studies. J Pharm Biomed Anal 2002, 30:1063-1074.

77. Mitra MS, Donthamsetty S, White B, Latendresse JR, Mehendale HM: Mechanism of protection of moderately diet restricted rats against doxorubicin-induced acute cardiotoxicity. Toxicol Appl Pharmacol 2007, 225:90-101.

78. Diaz JF, Strobe R, Engelborghs Y, Souto AA, Andreu JM: Molecular recognition of taxol by microtubules. Kinetics and thermodynamics of binding of fluorescent taxol derivatives to an exposed site. J Biol Chem 2000, 275:26265-26276.

79. Patwardhan G, Gupta V, Huang J, Gu X, Liu YY: Direct assessment of Pglycoprotein efflux to determine tumor response to chemotherapy. Biochem Pharmacol 2010, 80:72-79.

80. Bogin L, Degani H: Hormonal regulation of VEGF in orthotopic MCF-7 human breast cancer. Cancer Res 2002, 62:1948-1951.

81. Jin S, Scotto KW: Transcriptional regulation of the MDR1 gene by histone acetyltransferase and deacetylase is mediated by NF-Y. Mol Cell Biol 1998, 18:4377-4384.

\section{doi: 10.1186/1476-4598-9-145}

Cite this article as: Liu et al., Glucosylceramide synthase upregulates MDR 1 expression in the regulation of cancer drug resistance through CSrc and ?catenin signaling Molecular Cancer 2010, 9:145 